\title{
From the island's point of view. Warfare and transformation in an Andean vertical archipelago
}

Tristan Platt

\section{OpenEdition}

1 Journals

Electronic version

URL: https://journals.openedition.org/jsa/12817

DOI: $10.4000 /$ jsa. 12817

ISSN: 1957-7842

\section{Publisher}

Société des américanistes

\section{Printed version}

Date of publication: 5 December 2009

Number of pages: $33-70$

ISSN: 0037-9174

\section{Electronic reference}

Tristan Platt, "From the island's point of view. Warfare and transformation in an Andean vertical archipelago", Journal de la Société des américanistes [Online], 95-2 | 2009, Online since 10 December 2014, connection on 03 September 2022. URL: http://journals. openedition.org/jsa/12817 ; DOI: https://doi.org/10.4000/jsa. 12817 


\title{
FROM THE ISLAND'S POINT OF VIEW. WARFARE AND TRANSFORMATION IN AN ANDEAN VERTICAL ARCHIPELAGO
}

\author{
Tristan PLATT *
}

The article combines John Murra's theory of the " vertical archipelago " - a dynamic model of the changing historical relations between Andean societies, the complementary ecologies they inhabit, and emergent « State »-formations - with transformationalist theories developed among Amazonian peoples. Drawing on field-work with a longlived " archipelago » in the valleys of the Macha ayllu (Northern Potosí, Bolivia), the author shows the conflictive experience of valley " islands ", which must invert their moiety affiliations to survive pressures from the larger groups in which they are implanted. The confusion of levels of segmentation and the "island " formation produces different valley alliances from those sought on the puna, while presupposing a shared horizon of ideas concerning violence. Andean warfare is characterized by the same " ontological instability " at the blurred frontier between humans and animals that is found among other Amerindian groups, and elsewhere in the world. Different kinds of shapeshifting during fiestas and warfare, and the reformulation of animalhuman frontiers, are seen to be related to different social and historical contexts. [Key words: Andes, vertical archipelago, warfare, shapeshifting, socio-ontological frontiers, ethnohistories.]

La vision des îlots, guerre et transformation dans un archipel vertical andin. L'article intègre la théorie de l'« archipel vertical » de John Murra (un modèle dynamique des relations historiques changeantes entre les sociétés andines, les zones écologiques complémentaires qu'elles occupent et l'émergence de formations de type "étatique ») avec les théories transformationnistes développées pour des sociétés amazoniennes. Traitant d'un archipel attesté sur la longue durée dans les vallées de l'ayllu Macha (Nord Potosí, Bolivie), le texte expose l'expérience conflictuelle d'ìlots des vallées qui doivent inverser leur appartenance de moitié pour survivre aux pressions de groupes plus grands au sein desquels ils sont implantés. La confusion existant dans les vallées entre les niveaux de segmentation sociale entraine des alliances politiques différentes de celles qui ont cours dans les hautes terres, tout en présupposant un horizon partagé de représentations de la violence. On retrouve dans la guerre andine la même instabilité

- University of St Andrews, Centre for Amerindian, Latin American and Caribbean Studies (CAS), School of Philosophical, Anthropological and Film Studies, 71 North Street, St Andrews, Fife KY169AL, Scotland UK [tp@st-andrews.ac.uk].

Journal de la Société des Américanistes, 2009, 95-2, pp. 33-70. (O) Société des Américanistes. 
"ontologique» aux frontières de l'humain et de l'animal qui a été observée dans d'autres sociétés amérindiennes, ainsi qu'ailleurs dans le monde. Plusieurs types de transformations qui se jouent durant les fêtes et la guerre, ainsi que la reformulation des frontières animal-humain, apparaissent liés à des contextes sociaux et historiques eux aussi changeants. [Mots-clés: Andes, archipel vertical, guerre, transformations, frontières socio-ontologiques, ethnohistoire.]

Desde la perspectiva de la isla, guerra y transformación en un archipiélago vertical andino. El artículo combina la teoría del « archipiélago vertical » andino propuesto por John V. Murra - un modelo dinámico de las cambiantes relaciones históricas entre las sociedades andinas, los nichos ecológicos complementarios que habitan, y las formaciones « estatales » emergentes - con las teorías transformacionalistas desarrolladas para los pueblos de la Amazonía. Basado en un trabajo etnográfico realizado con un « archipiélago » de larga duración en los valles del ayllu Macha (Norte de Potosí, Bolivia), este texto muestra la experiencia conflictiva de algunas « islas », que deben invertir su pertenencia de parcialidad ( mitad », o saya) para poder persistir entre los grupos mayores que dominan su vecindad. La confusión entre los niveles de segmentación y la formación de las « islas » exigen otros patrones de alianza que los que se dan en la puna, compartiendo sin embargo ambas regiones un mismo horizonte de ideas con respecto a la violencia. La guerra andina se caracteriza por la misma « inestabilidad ontológica » en la frontera borrosa entre animales y seres humanos que ha sido encontrada en otros grupos amerindios, como también en otras partes del mundo. Se muestra que los diferentes tipos de transformación, y la reformulación de las fronteras entre animales y humanos, pueden ser relacionados con diferentes contextos sociales e históricos. [Palabras claves: Andes, archipiélago vertical, guerra, transformaciones, fronteras socio-ontológicas, etnohistoria.]

In memoriam John V. Murra (1916-2006)

I propose in this article to relate two theories, each of which has given rise to extensive debate but has not yet been integrated with the other. One, the " vertical archipelago ", is considered almost diagnostic of Andean economic organization, and is supposedly irrelevant to the Amazon (see, however, Uzendoski 2004). This was one of the late John Murra's characteristic themes: he analyzed the " vertical control of a maximum of ecological levels » in Andean societies whose nuclei of power were situated at different altitudes, and sought to understand the sociological and political implications of the "multi-ethnic » organization of distant resource-niches (Murra 1975 [1972], 2003 [1973]; Masuda, Shimada and Morris 1985). The other topic, that of human-animal transformations, has been developed strongly in Amazonian studies, although with little recognition of its possible resonances in the neighbouring Andes. It deals with the " ontological instability » of the frontier between animals and humans at the temporal and 
social margins of human society (see e.g. Viveiros de Castro 1998). The transformation of warriors and shamans into animals (whether wild, khuru, or domesticated, $u y w a)$, and their oscillation between the human and the animal, can also be found among Andean shapeshifters, both in the mythohistoric past and in the present.

To relate these two themes, I draw on ethnography carried out during 19701971 with the Macha ethnic group (Northern Potosí, Bolivia). I show the transformations that occur in practices of alliance formation and the choice of enemies when highland populations send out colonists to settle in the warm maize-producing valleys below. But to explain the new perspectives on violence that emerge in the valley " archipelago ", we must situate these settlers within the wider horizon and ethos of regional warfare. In Macha, as elsewhere in the North of Potosí, warfare and the warrior ethic permeates traditional society; but there is an important difference between " balanced competitions » (tinkus) and "unbalanced destruction» (ch'ajwas). I have elsewhere suggested that the imposition of the pax incaica meant transforming ch'ajwas into tinkus, thus restricting open warfare and encouraging the emergence of competitive " games » (pujllay) at regular points in the ritual cycle (Platt 1987a). Of course, it is not always certain, even today, that a tinku may not become a ch'ajwa, particularly if celebrated away from the parish capitals in the open countryside. But the oscillation between tinkus and ch'ajwas is not simply a matter of more or less violence; a tinku may throw into relief the underlying social conflicts and contradictions between ayllus and moieties and, more broadly, between Indians, mestizos and the State; but a ch'ajwa may seek a radical transformation of these relations between individual, community and the wider society. I suggest, moreover, that we try to relate changes in societies' ideas of the relation between animals and humans to historical events, with the aim of bringing history back into discussions of transformationalism, as I shall propose in the conclusion.

The article therefore argues for the value of expanding both Amazonianists' and Andeanists' universes of reference towards each other, and towards South America as a whole. Such an anthropology sees structural transformation and phenomenological perception as the outcome of collective and personal histories; and it is this approach that Murra lived, practiced and urged us to follow.

\section{TRANSLOCATION AND TRANSFORMATION}

Crowned on the high puna by specialized pastural societies reaching up to 4500 masl (Flores 1979; Dransart 2002), the unique geo-ecological features of 
the tropical Andean environment were surveyed by Carl Troll (1968), who drew attention to the high-altitude resources which had made possible the development of Andean civilization. Following Troll's lead, in the 1960s Murra encouraged interdisciplinary research into the vertical organization of Andean societies of varying scale, with centres of authority situated at different levels of altitude. Highland societies, for example, with their ancestral devotions, cold puna agropastural economies, and sacred geographies, had chosen to re-adapt themselves through settlement to new conditions at lower, warmer altitudes; yet settlers below still retained access to cold puna lands and resources through their highland kin, with whom they shared ethnic affiliations.

Murra coined the metaphor of the « vertical archipelago » to characterize the society emerging from the intermingling of colonists from different groups at the limits of their core societies' political reach, both upwards and downwards, and on both Pacific and Atlantic sides of the Cordillera. Settlers were seen as living like " islands » in " multi-ethnic » neighbourhoods alongside other " islands » placed there by other groups ${ }^{1}$. And he saw the resettlement of populations, or mitimaes, by the Inca State as a transformation of the « vertical » model, in which the ideal of maximizing each society's resource base was transcended by State economic, military and political strategies(Murra 2003; Saignes 1985; Presta 1995) ${ }^{2}$.

Murra argued that his model was also applicable to periods « immediately prior $"$ to the emergence of Andean States, constraining the form of their development. For these « intermediate periods » between successive State formations, he predicted the discovery of a " network of contradictory claims, temporary adjustments, tensions, struggles and truces between various regional nuclei who shared the same ideal [of verticality] in a stage immediately prior to the formation of the archaeologists' "horizons" " (Murra 2003, p. 91) ${ }^{3}$. But the ways in which these conflicts were experienced, balanced and provisionally resolved has remained obscure.

The Macha ayllu today speaks a dialect of Quechua, considerably influenced by Spanish and Aymara, but is derived historically from the leading social unit in the pre-Hispanic Aymara-speaking federation of the "White Charka ", or Qaraqara, one of the largest societies within the Inca « Province of Charcas » (to the south of modern Oruro). Macha continued to exercise considerable political protagonism during colonial and Republican times (Platt, Bouysse-Cassagne and Harris 2006; Serulnikov 2006; Platt 1982a, 1987b). Moreover, we now have evidence that the local « archipelago » of San Marcos de Miraflores, where I lived in 1970-1971, had persisted, with remarkable continuity on the ground, since well before the late 16th and early 17 th centuries, when it was observed and described by early colonial land Inspectors (visitadores) ${ }^{4}$.

Part of my argument concerns the language we use to talk about « vertical social organization ». Murra's own phrase, the vertical "archipelago », is a powerful metaphor for emphasising the interdigitated pattern of discontinuous 
territoriality $^{5}$, but it may also screen out alternative ways of imagining the situation. It seems to imply a sea with a group of islands at some distance from the nearest continent. But where is the "sea »? Does it represent the land-limits between neighbouring ethnic « islands »? Or the transitional " middle region » (chawpirana), which settlers from the highland "continent " must traverse to reach their valley lands? And how are we to understand situations where, as in the Macha valleys, lone households belonging to one group, or ayllu, may be surrounded by a group of houses belonging to another? As "little islands » within « larger islands »? The picture becomes complex...

How, then, is « verticality » spoken about in Aymara and Quechua? What other linguistic expressions are available for expressing the social relationships behind the archipelago metaphor? We will consider two « metaphors people live by " in the Andes (to use Lakoff and Johnson's suggestive phrase): weaving and vegetable reproduction ${ }^{6}$. In 1985, Olivia Harris suggested comparing North Potosi spatial organization with the organization of woven space revealed by Cereceda's work (1978) on design complementarities in the weavings of Northern Chile (Isluga). Harris argued that North Potosi farmers living at the highest levels of settlement tended to have their valley lands in the lowest regions, while those living in the « middle region » (Que. chawpirana; Aym. taypirana) between puna and valleys could extend upwards and downwards within relatively easy reach of their nuclear settlements. She compared this distribution with the spatial grammar of geometric textile designs, as revealed by Cereceda, where the symmetrical bands on the opposite ends of rectangular pieces of cloth are contrasted with the fertile band, or " heart ", located at the centre of the design. The climatic gradations from high to low within the chawpirana were compared with the chromatic degradations ( $k^{\prime} i s a$ ) that may mediate between two opposing colours in the "heart » of Isluga textiles. Harris did not discuss the " archipelago » settlement pattern, and her emphasis on the relative self-sufficiency of the centre has still to be demonstrated ethnographically in North Potosí (see Mendoza and Patzi 1997 for further data); but the idea of social cloth is reiterated in the Quechua and Aymara imagery of "island-hood » to be found in the Macha valleys. Indeed, one valley « islander » I spoke to likened his precarious situation to that of a " snapped thread ", a vivid image of separation and difference which captured both his distance from his puna ayllu-mates and his isolation in relation to his valley neighbours.

Another form of expression for vertical settlement can be derived from processes of vegetable reproduction. Two mallki - paired shrubs which embody an apical couple - can be found in several ethnohistorical contexts (see, for example, Pachacuti Yamqui Salcamaygua 1993 [1613]). They reappear in Macha today as the two sprigs of evergreen pepper-tree (molle) placed at the head of ritual «tables » (mesa/misa $=$ altar/mass) as symbols of perennial fertility; and also, merged, as the trees that grow in front of churches in the squares of early 
colonial Indian towns (reducciones), and whose divided male-female roots are said to reach out to sustain every household in the parish (Platt 1978; 1996, note 15). While drawing diagrams of the valley and puna segments of vertically connected kin-groups, I wondered how their respective household "roots" (saphi), believed to connect locally with these trees and towers, might also be connected across the intervening slopes of the Eastern Cordillera. A possible solution was offered by a Macha acquaintance, who told me that mallki was the name in Quechua of « plants that send out other plants ». Could vertical links be imagined as subterranean root systems (suckers), or as the "runners" of strawberry-plants? Had settlers to "re-root themselves » as valley islands, after being sent down from their parent kin-groups on the puna ${ }^{7}$ ?

In this article I show how settlers descending from the puna, while replicating their social organization at lower levels of settlement, also introduce modifications in the valleys arising from the compressed coexistence of different levels of social segmentation within a shared space. These adaptations of highland organization are surprisingly systematic, while at the same time they give rise to situations of ambiguity; yet they have enabled « islands » with multiple affiliations to coexist within these intermontane valleys and render them habitable.

Another important feature of the region is a long tradition of warfare between neighbouring groups at different levels of segmentation (Platt, BouysseCassagne and Harris 2006). However, the islands' identification of enemies and allies, of those who can be fought and eaten as opposed to those with whom one shares battle-lines and commensality, is, as I have suggested, significantly different from the identifications made on the puna. Other ayllus of the same moiety would be considered allies on the puna; but they may be recategorized by valley islands as enemies. Equally, ayllus of the other moiety, considered enemies on the puna, may become allies in the valley archipelago context. The polar opposition between moieties (Anansaya and Urinsaya, « upper » and " lower halves ») thus becomes mediated by degrees of intermediate experience, leaving open a range of ambiguous social definitions which characterise vulnerable valley islands. An analysis of these differences between highland and lowland alliance formation will lead us into the heart of the vertical archipelago.

As is well-known, today ritual battles, or tinkus, occur all over Northern Potosí, generally in towns or villages, and associated with the dates of different Catholic fiestas. These battles are, among other things, rituals of confirmation of different groups' access to land; alliances are tested and tried; and individual men may present themselves as fierce bulls that battle together to show their prowess, each rivalling the other with drunken shouts of turu kaniy, carajuuu! « I'm a bull, shiiit! ». Fights generally occur under the vigilance of the town authorities in the squares and at street-corners of regional towns and parishes (Platt 1987a; Harris 2000). In the puna town of Macha, the participants are generally from the two opposing moieties; but, further down the eastern side of the Cordillera, the 
moieties may unite to present a united Macha front to a neighbouring ethnic group which shares the same parish jurisdiction (e.g. when fighting with the Pocoatas in the chawpirana town of Surumi). Still lower, these groups may in turn ally against a rival alliance (such as K'ultas and Macha Anansayas against Macha Urinsayas in San Marcos de Miraflores; or Machas and Pocoatas against Laymis and Purakas in the old red-pepper and cotton producing town of Carasi). As one descends, the local representatives of more embracing classifications may suspend hostilities and become allies against a rival bloc.

In contrast, the more ferocious confrontations known as ch'ajwas occur far from the watchful eyes of mestizo authorities, the police, the military, and - today - thrill-seeking tourists. If tinkus are a violent game (pujllay), these other battles in the depths of the mountains are seen as serious warfare; even seasoned warriors become apprehensive. Here the male members of ayllus or moieties may range themselves against their opponents in battles over land-limits, resorting to slings, arson, gang-rapes and sometimes guns; behind the lines they may be supported by singing women who prepare chicha against their return. In puna ch'ajwas, where lines of warriors may confront each other with slings or fall to grappling hand-to-hand, men are sometimes said to take the shapes of wild animals (khuru): the frontiers between humans and wild animals become blurred and unstable. Transformed into bears (jukumari), owls (juku) or pumas (puma), predatory aggression by warriors who have become wild animals replaces their transformation during tinkus into the fiercest of domestically-reared animals, fighting bulls.

The social, symbolic and ritual identification of Indians with domesticated animals (uywa) during peacetime is well-documented throughout the region (Abercrombie 1998; Stobart 2006). In rituals accompanying the fiesta of Corpus Christi in the valley town of San Marcos, men don the carrying bags of llamas (kustalas, Sp. costales), or the skins of sheep and goats; or they may become yokes of man-bulls (all are called collectively jañachus, or « stud llamas »). Meanwhile local mestizos act out the parts of foxes or pumas, who attack the Indians playfully, and try to steal their animal skins in a burlesque representation of local relations of power (Platt 1996). The traditional élites of rural society - hacendados and dominant mestizos - embody natural powers, animals and birds, but also metereological threats. As patrons of lightning and thunder, for example, they are said to ride through the clouds with silver bits and stirrups, letting off their guns, or arquebuses, whose bullets streak to earth as thunderbolts (balas), sacralizing " places " and initiating male shamans and female midwifes into the preconditions of their arts (Platt 1997, 2001; Platt and Quisbert 2007). The ayllu is the locus and refuge of sociality, cultivation and domestication; whereas wild places, animals and other natural phenomena are potential sources of sacred power associated with other kinds of " people » beyond the ayllu ${ }^{8}$.

In ch'ajwas, however, the normal order of things is destroyed as people battle to incorporate disputed territory into their jurisdiction. Transformed fleetingly 
into wild animals, warriors acquire sacred power, and may tear their enemies apart, drink their blood and eat certain organs - tongue, liver, heart, testicles, etc. in acts of frenetic exocannibalism. In so doing, it may be said that they resuscitate the ambiguous role of wild animals during the feral chullpa age, the mythic " unquiet time " (inkyitu tyimpu) of the moonlit ancestors before the rising of the Inca-Hapsburg Sun, when wild creatures could become humans, and humans wild animals (Platt 1978, 1996a, 2001; Stobart 2006). This is the time called by Guaman Poma the "Age of the Warriors » (awka runa or aucuruna), and it is situated before the arrival of the Incas, coinciding with the Late Intermediate period described by Murra and others as one of extreme social tension and instability. The fluctuating identities of chullpas during this «lunar age » of warfare and enmity are reminiscent of the violence and anarchy of the ch'ajwas, when order and frontiers are similarly suspended and disputed, and the preconditions for peaceful coexistence break down. Social relations are dissolved as the ambiguous identities of chullpa animals re-emerge, and the shamanic capacity for transformation is acquired by the fiercest warriors in each army ${ }^{9}$. In ch'ajwas, activities in present time resuscitate mythic past time. In a sense, these battles may even be said to take place " out of time " and " out of society ", re-enacting mythohistorical relationships that continue to underly and sustain the formation of the present social age. Yet from another perspective, they can be dated and related to the history of local, and even national, political relations.

It should be remembered that, today, wild animals such as the puma are said to be the mountain shepherds (awatiri) of domesticated animals, at the same time as they prey on them and consume them as food. In their wild animal transformation, equally, warriors attack and consume their enemies, who thus become domesticated animals which fall victims to feral predation. As humans, however, warriors may be said to sacrifice their enemies, pouring their blood on the ground as appeasement for hungry and angry earth deities, eating their vital organs, but burying the remnants (especially skulls, or kawisas, Sp. cabezas) as offerings to feed and placate the hungry hills and mountains. This may suggest one reason why it has always been difficult to distinguish between the sacrificial and predatory aspects of Andean warfare.

It is within this wider context of cosmic confrontation, of warfare as " play " and as destruction, that the " confused » valley situation represents an important and little-understood situation of mediations and attenuations. While part of the wider Macha religious and social universe, it has distinctive characteristics of its own, which confirm the intuition which Murra brought to bear upon the instabilities, temporary alliances and conflicts that marked the « multi-ethnic archipelagos » of the Late Intermediate, places of inter-ethnic mixture and juxtaposition at the further reaches of Andean societies' power to colonize and share distant ecological niches. 


\section{Approaching the Macha archipelago}

Puna llama-herders travel down to the valleys each year, generally between April and September, to take part in exchange relations with kin and other exchange-partners in the old colonial parish (doctrina, reducción) of San Marcos de Miraflores, most of whose population was (and, to some degree, still is) connected with landed groups and kin-networks up on the distant puna around San Pedro de Macha ${ }^{10}$. It takes two weeks to travel down with llamas from the puna to the valleys, and 3-4 days without llamas. Andean peasants inhabit their environment by traversing it, and disputing it in the process of transforming it. Access to paths and common pastures is generally permitted to travellers in times of peace; only when conflicts over land have established opposing battle-lines, stretching over hills and valleys and guarded by « sentinels " (sentinelas), may passage be regarded as a provocation. Travel between puna and valleys maintains a network of rural footpaths (chaki ñan) which criss-cross Macha vertical territory. These are marked at intervals by shrines and ceremonial sites related to passes (apachita) or to striking features of the sacralized landscape. At the entry to the valleys, the trail passes between two great peaks, one for each moiety, where the puna authorities used to sacrifice and pour libations to ensure the fertile relation between lowlands and highlands. Here we find traces of a formal ceremonial relation between puna and valley, and a "rite of passage " between them ${ }^{11}$.

From the valley point of view, relations with their puna kin are experienced with considerable ambivalence. Some say that « robber mountain-spirits » (suwa jurq'u) from the puna may come and eat up their maize in a storm of hail, unless scared off with explosions of dynamite. In their seasonal visits, llama-herders may bring exchange goods with them: salt, clay and ceramics, and other mineral resources, as well as highland herbs and coca-leaf (a lowland product bought in highland market-places); but there is still debate as to whether valley maizefarmers are the complementary partners of the puna llama-drovers, or whether the latter are exploiting valley residents by carrying off their maize ${ }^{12}$. After the biggest tinku on the Macha puna at the fiesta of the Holy Cross (May 3rd), which takes place in the old colonial town of San Pedro de Macha, puna llama-herders (llameros) set off for the distant valleys, where the biggest valley tinku is held a few weeks later in San Marcos de Miraflores at the feast of Corpus Christi, with the participation of both highland and valley ayllu members ${ }^{13}$. Llama-herders may be absent for three or four months before returning with their llamas loaded with maize, which will see them through the growing season before the early potato crop appears in February or March. It is then the task of the women, as controllers of the larder (dispensa), to ensure that the maize supplies stored in the sacks and granaries (pirqa) "last out» (muchuy, or awantay see Sp. aguantar) until next year's food becomes available. 
Land in the Andes is a vulnerable resource in constant need of labour, both in its preparation and cultivation, and in its administration, defense, ritual nourishment and ceremonial propitiation. Warfare itself is sometimes conceptualized in terms drawn from the organization of labour (e.g. chuqhunaku, where many people set on a single victim, derived from chuqhu, collective labour effort convened by a single beneficiary, and the Quechua interactive suffix -naku). Local activities are combined with negotiations with higher levels of organization and, ultimately, with local and regional representatives of the State, which since the late 18 th and 19th centuries has been eager to privatize land and abolish collective claims. At the same time, the trappings of an older reciprocal arrangement are maintained: the exchange of service and tribute for protection and land, as developed between Aymara lords and tributary vassals since the Inca and early Hapsburg States in the 16th century (Platt 1982a, 1984, 1996; Platt, BouysseCassagne and Harris 2006). It may be inferred that these marginal expressions of State-community relationships (tribute-payment, provision of postillions, labour services, etc.) are characteristic of a different, older kind of State from that which, in Republican times, has sought land-privatization, the creation of a landmarket and a new land-tax based on the formation of a Catastro. Prestations for what I have called the Inca-Hapsburg State, it may be argued, are still being made at the margins of the expansive thrust of the new post-Enlightenment form of liberal State.

I have elsewhere discussed how Macha ayllu-members explained to me the segmentary principles behind the formation of their military alliances (see Appendix; also Platt 1978, 1996). But discrepancies emerge when we compare this ideal account with patterns of residence and social affiliation on the ground. Whereas parts of the segmentary model may be trotted out by Macha peasants to explain why different groups ally and confront each other, an examination of specific contexts of alliance and opposition reveals a more confused and complex picture. Nowhere is this confusion greater than in the valley « archipelago » of San Marcos de Miraflores (see Figure 1).

Macha society is divided, today as in the 16th century, into four main segmentary levels, and at each level the term " ayllu » can be applied: so we find ayllus within ayllus within ayllus within... Insiders and outsiders are relative statuses: enemies at one level in the hierarchy are friends at another level. The maximal level of the Macha ayllu is divided into two gendered moieties (Alasaya, " male upper » and Majasaya, " female lower »); ten minor or « child ayllus » (churi ayllu), five in each of the moieties; and a variable number of cabildos or minimal ayllus which today have replaced the decimal pachaqa, or " hundreds ${ }^{14}$ - probably an Inca innovation - referred to in the 16th century sources. Most cabildos have land both on the puna and in the valleys ${ }^{15}$. Clearly, given this hierarchy of nested identities, several answers can be given to any question about a person's identity, residence or ayllu membership (Platt 1978). 


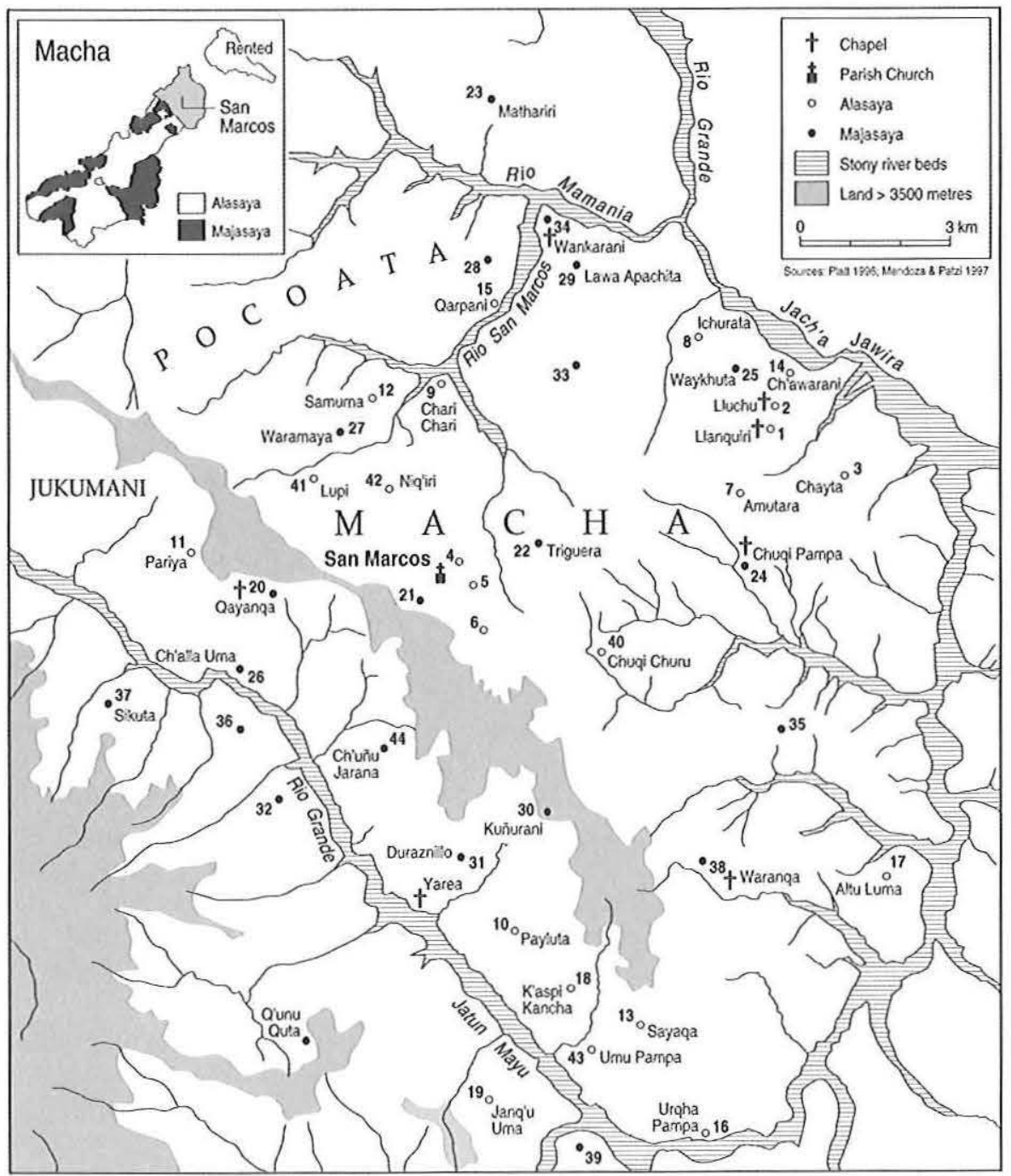

FIG. 1 - Distribution of Macha lands in San Marcos de Miraflores (map drawn by Graeme Sandeman).

Dispersed over each cabildo's territory lie the patrilocal hamlets (estancias, or ranchos) or isolated homesteads of the Indian peasants. In the puna section of each cabildo the territorial group is made up of several named hamlets and their lands; and each hamlet is composed of the descendents of one or more ancestors recognised and assigned a land-holding (tasa) during the last Governmentsponsored inspection (revisita) in the last decades of the 19th century ${ }^{16}$. 
Possession of a tasa confers rights to a share in the highest common lands (mantas ${ }^{17}$ ), cultivated in a 3-4 year cycle of crop rotation, and then left to fallow over long periods. Landholders' need to coordinate rotation cycles and agree the moment for opening a new bloc of fallows underlies the tendency towards nucleated hamlets to be found on the puna. Indeed, mantas are found mainly on the puna (patarana, chirirana: « high » or « cold » region), and competition over a choice, well-rested bloc of fallows is a common pretext for inter-ayllu warfare (ch'ajwas) (Platt 1982b).

But in the warm lands (urarana, q'uñirana: « low » or " hot region »), each farmer lives in an isolated dwelling surrounded by his maize-plots. Here, a family's local tasa may consist of several plots scattered between a range of local microclimates, from the higher levels (patarana) and middle hillsides (chawpikinray) down to the riverbeds (mayurana, "river region ») ${ }^{18}$. The differences of settlement pattern in puna and valley reflect differences in the agricultural system of each " production zone " (Mayer 2004); and it is clear that the isolated valley pattern is more compatible than puna hamlets with the emergence of individual « islands ».

How does ayllu segmentation relate to the actual alliances and oppositions entered into by Macha peasants? A dispute between two groups at the same level, but each belonging to different higher-level groups, should (I was told) produce the fusion of all those groups on each side that share membership of the same higher-level group (Platt 1978). This would mean that people not directly involved in a local confrontation may be expected to come to the assistance of those in the same structural category as themselves, in exchange for reciprocal support in their own local conflicts. But this pattern is not followed consistently, partly because of increased localization within the State administrative system ${ }^{19}$; and partly because, while the « segmentary imperative » is part of a Macha theory of their own social organization, it does not « account for » all the ambiguities of real-life situations.

Finally, although documentary evidence shows that the moieties and minor ayllus of Macha have remained unchanged in name and number since the 16 th century, the cabildos seem to be more flexible. They sometimes split and regroup, appear and disappear, according to local demographic and political pressures. Indeed, institutional flexibility at this level may underlie the greater degree of stability at the higher ayllu levels (Platt 1982b).

\section{NEIGHBOURHOOD SOLIDARITY AND SHIFTING AFFILIATIONS}

Isolated households on the internal frontiers of Macha valley organization must strive to conserve access to their land in the face of pressures from dominant neighbours with different vertical affiliations. These solitary « islands » represent 
a limit case in Macha society, and their situation differs significantly from that of the large cabildos and minor ayllus on the puna. Indeed, they must sometimes suspend their moiety aftiliations, where these conflict with those of their dominant neighbours, as a concession to the need for neighbourhood solidarity. So, in the valley, the ayllu and moiety membership of the occupier of an island may be attenuated, inverted or "exchanged » to secure his/her access to an isolated parcel of land.

Murra's " archipelago » formation can be recognised at once in Figure 1, which shows the vertical affiliations of each « island » I was able to identify in the Macha valleys. A word of explanation before looking at the social relations involved. When I first went to live in the Macha valleys in 1970, I had no idea of the scale of organization in which local peasants were involved. There were no previous ethnographic studies anywhere in Northern Potosí, and it was only after several weeks that people's historic relations with the distant puna began to dawn on me. One day, three months after my arrival in San Marcos, I was told how the Machas and two other maximal ayllus, the Pocoata and the Laymi, had begun their descent from the puna, and reached Carasi. Carasi is a neighbouring Canton further down the Río Grande, or Jatun Mayu, where red peppers, squashes, cotton and sugar-cane can be grown ${ }^{20}$, as well as maize, and where these three maximal ayllus possess territorial "islands ». But in Carasi the sandals of the Laymi broke, while the Pocoata and Macha continued their descent, finally reaching Mizque many leagues away in the Department of Cochabamba, where the boundary-stone of « the Charcas » can still be found ${ }^{21}$. Alerted in 1969 by John Murra to the importance of vertical organization in the Andes, I pricked up my ears and began to wonder about the social and symbolic implications of what I was hearing.

But the accounts of Macha " vertical organization » which I received in the valleys at first seemed confused and inconsistent. Some people told me that there were actually twelve ayllus ${ }^{22}$, although by the time I left San Marcos after Corpus Christi in June 1971 I had collected the names of many more local social groupings than twelve... Others asserted that there was only one kuraka for both moieties on the puna, a possible reference to the ancient alternation of overlordship between the two moiety chiefs (see Platt, Bouysse-Cassagne and Harris 2006), or to the effective survival in the 1970s of only the Alasaya curacazgo. Still others used ayllu or cabildo names as toponyms, or used toponyms to designate social groups; and the levels of contrast were confused in relation to the segmentary model. Indeed, before going to the puna I did not understand the distinction between a minor ayllu (or churi ayllu, «child » ayllu) and a cabildo (or minimal ayllu), for it was seldom relevant to valley alliance-formation.

The "Yuqhunas », for example, dominate the central area around the town of San Marcos itself (see 21 on the Figure 1). They are considered equivalent to other groups, such as the "Amutaras» (7), or the "Lluchus » and 
« Chaytas » $(2,3)$. It was only on the puna that I was told that the Yuqhunas were a cabildo of minor ayllu MajaQuyana, that Amutara was in fact the name of a mountainside opposite San Marcos where the cabildo Yuraqari (minor ayllu AlaQuyana) had its valley lands, and that Chayta and Lluchhu were valley parish annexes where the cabildos of Ayuma, Pichichhua and Pumpuri (also of AlaQuyana) had their valley lands intermingled. Toponyms and different levels of organization, usually distinguished on the puna, were being mixed in the valleys to designate the social contrasts relevant to life in San Marcos.

Again, on another occasion I was told that the Waraqhatas $(11,12)$ would be fighting against the Yuqhunas (21). Only when I reached the puna did I realise that, though demographically balanced in the valleys and hence considered equivalent fighting partners, the two groups in fact belonged to different levels of segmentary organization: a churi ayllu name was being considered equivalent to a cabildo name. My perspective in the valley was also affected by the fact that I lived in Yuqhuna in an abandoned thatched-adobe hut (built as a school and twenty minutes walk from the ruined town of San Marcos). I was being presented with those contrasts of social membership particularly relevant to my status as resident of Yuqhuna; and I found that, similarly, most peasants often « know » only those aspects of social organization that directly concern them ${ }^{23}$.

Figure 1 therefore gives information collected in the valley, but supplemented with glosses in the light of the tributary system explained to me later on the puna. This has the advantage of allowing a more precise identification of each local group. But not all this information was considered relevant, or even known, by all valley-dwellers all the time. Local features of organization were developed and reproduced for most of the year with little need to take account of the formal segmentary model preserved in the puna kurakas' tribute lists. And in some cases, the dispersal of minor ayllus in the valley had led to the appearance of contrasted groupings not recognised at all in the general puna model. The Wakhuatas of Wilakota (35), for example, are contrasted in the valley as jatun wakhuatas ( " greater Wakhuata ») with those of Ilili and Sikuta $(36,37)$ who are called churi wakhuatas ("child Wakhuata»). Again, the Sullkhawis of Chhari-chhari and Ichurata $(9,8)$ are respectively distinguished as juch'uy and jatum (" lesser » and " greater »). From a puna perspective, such local contrasts are not perceived to be part of the general organization of Macha society, although similar contrasts are also built into local puna forms of self-identification ${ }^{24}$.

One dominant contrast, however, appears to be shared by both regions: the two moieties, theoretically endogamous, are opposed in many ways, but especially by the violent hostility which flourishes between them during tinkus and ch'ajwas. All Macha folk can be classified by themselves and others as either Alasaya (" upper half») or Majasaya ("lower half») (see Figure 1). It is a surprising feature of valley society that even this all-embracing opposition 
becomes blurred and problematic when we observe the vulnerable and contradictory position of many « island » enclaves.

Let us consider cases where Alasaya « islands » are surrounded by a Majasaya neighbourhood, and vice versa. How can this heterarchic, unequal situation be maintained? Note first the different levels of segmentary organization at which an island may be contrasted with its neighbours.

1. An island of one moiety may be nested inside the other moiety; e.g. Sullkhata (Majasaya, 33 on the Figure 1), inside Sullkhawi (Alasaya, 28); or Kuimuri (AlaQuyana, 5) inside Yuqhuna (MajaQuyana, 21).

2. An island of one minor ayllu may lie inside another minor ayllu of the same moiety; e.g. Taphunata (15) inside Sullkhawi (28), both of Alasaya; or Kunthawata (4) inside Yuqhuna (MajaQuyana, 21), both of Majasaya.

3. An island of one cabildo may be set inside another cabildo of the same minor ayllu; e.g. Kunthawata island 13 inside Kunthawata island 31 (precise identifications uncertain).

4. One group comes from a different maximal ayllu altogether: the K'ultas of Llanquiri (1) inside the Macha AlaQuyanas of Chayta and Lluchhu $(2,3)$. Here the island/neighbourhood contrast occurs at the level of the maximal ayllus involved.

We can appreciate the complexity of a situation sometimes glossed simply as "multi-ethnic " in the ethnohistorical literature on archipelagos and their " islands ». In fact, vertical afliliations combine with the segmentary system to establish several degrees of social contrast between different « islands » and their surrounding neighbours, and this continues down to levels well below the maximal level of ayllu contrast. The question that now arises is how these subtle gradations of contrast between islands and neighbours at different levels can be reproduced over time. Here it will be useful to distinguish between those social relations which pertain to the local neighbourhood, and those expressing the vertical affiliation of each household to its kingroup, cabildo, ayllu and moiety on the puna ${ }^{25}$.

Let me now present four contexts where the vertical ayllu affiliations of each valley household take clear precedence over membership of the local neighbourhood:

1. Tribute payments. Payment ceremonies (also called cabildos) are held in the valley and are attended by all the scattered representatives of each territorial cabildo and minor ayllu within San Marcos. As a rule, the cabildos for the St John semester are held in the valleys, since much of the puna population are also in the valleys at that time (June 21st), engaged in exchanging salt, chuño (freeze-dried potato) and other highland products for the maize they need to survive the puna growing season. Each cabildo is sponsored by a cobrador (collector) named by turn for the year, who must provide the chicha, coca and alcohol for the ceremony. Here, as we have seen, the 
tribute-paying ceremonies act to bring together the scattered members of each social group, whether they are normally resident on the puna or dispersed among different enclaves in the " mixed-up " valleys ${ }^{26}$.

2. Vertical exchange. Between April and September each year, the llama-trains descend from the puna across mountains and through gorges, along river-beds and down ravines, crossing passes between descending mountain peaks, until they reach the warm maize-producing valleys where they can engage in exchange relations with their kin, ayllu mates or other trading partners. This is the classic rationale for vertical affiliations, and has been well described for Macha by Cassandra Torrico (n/d), who shows how the stripes on the woven bags in which the llamas carry their loads themselves symbolize the major exchange products of each zone, propitiating successful transactions and the acquisition of sufficient food (especially maize) to last through till the following year.

3. Corpus Christi. In May or June, all puna visitors come together in San Marcos with their valley comrades to participate in the great moveable feast of Corpus Christi (or, in the case of the K'ultas of Llanquiri, San Pedro on June 29th). Here, the maize harvest is celebrated with a Mass dedicated to the Host (the solar body of Christ), and offerings are made to propitiate a successful year ahead. A massive tinku also takes place, in which puna visitors and local residents are expected to combine according to their ayllu and/or neighbourhood affiliations (Platt 1996a).

4. Vertical duties and services. Security of landholding also requires the performance, in the name of one's moiety, minor ayllu and cabildo, of certain labour services to the State, of which the most important in colonial times was the mita service in the silvermines of Potosí (Saignes 1985; Tandeter 1992; Platt 1983). Households enjoying access to land in both ecological zones were also expected to take part in sponsoring religious feasts in each zone, and to serve as tribute collectors (cobradores), alcaldes and couriers. A courier service was maintained until 1972 in the tambo (inn) of the town of Macha on the puna, where travellers were provided with food and lodging (each moiety had its own kitchen garden): landholders of puna and valley would be named in turn to perform this task ${ }^{27}$. Similar obligations were expected of the valley K'ultas, who in 1971 still performed their postillion service in their puna town of Santa Barbara de K'ulta, Department of Oruro ${ }^{28}$.

This list is not meant to be exhaustive, but it illustrates a range of contexts in which vertical affiliation is paramount. For much of the year, however, neighbourhood issues predominate over vertical considerations, and islands with a different vertical affiliation from that of their engulfing " hosts 》 must find some modus vivendi to ensure their own survival. To see how this is achieved, let us consider some specific cases:

1. Island 4 is an isolated Sullkhata (cabildo Juluch'i) who was well aware of his conflictive position surrounded by Yuqhunas (minor ayllu MajaQuyana, 21), even though both minor ayllus belong to the same moiety of Majasaya. This was the man who said he was p'iti-jta-sqa (where p'itiy means " to break or snap (a thread) ", ljta/ is an Aymara affix expressing the idea of "sudden separation ", and /sqa/ here indicates 
the past participle). The image belongs to the vocabulary of spinning and weaving, and confirms the metaphor for geographical organization which Harris derived from Cereceda's work on textile design. The island-dweller represents himself as a " broken thread $»$ in the supposedly smooth weave of neighbourhood and moiety organization. This condition has consequences for his choice of allies and the identification of his enemies. Hence he spent the May 3rd feast of Father True Cross, Tata Wilakrus ${ }^{29}$, sometimes with the Yuqhunas and sometimes with the nearby Sullkhawis (9) from the opposing moiety of Alasaya.

Tata Wilakrus is the name given to big wooden crosses, painted with fertility symbols and housed in little chapels (calvario) generally built on the tops of small hills in each neighbourhood. They are the male partners of the virgins (wirjinas) who reside in the nearby fields. For the feast, they are dressed by each local congregation in a poncho and helmet, with a coca-wallet and woven belt (chumpi). Then each is carried on a warrior's shoulder amidst the local group of helmeted indians, whose julajulas (panpipes) intone something like a Gregorian chant to the strict rhythm of a long-paced military march from the hamlet to the parish church. Here the Tata Wilakrus will hear mass and preside over the ritual battle (tinku) at the end of the fiesta (Platt 1996; Stobart 2006 on the music and dances of warfare).

By joining on certain occasions with the enemies of the Yuqhunas, this isolated Sullkhata therefore showed his own insecurity, and his willingness to seek support from both moieties whose lands are close to his own, either of whose Holy Crosses may provide fertility and protection for his land.

2. At Carnaval, the two moieties Alasaya and Majasaya form two different and opposed ceremonial groups, except for the islands, who again join with the group dominating their neighbourhood to celebrate another local fiesta marking the transition from the wet growing season to the dry season's time of maturation and harvest ${ }^{30}$.

3. Island 5 belongs to cabildo Kuimuri of AlaQuyana (Alasaya). Its occupier found that living surrounded by Majasayas (cabildo Yuqhuna, minor ayllu MajaQuyana) was such a strain that he decided to let his lands to a tenant from Majasaya (minor ayllu Wakhuata, 5) who might be expected to have more relaxed relations with the dominant local group.

4. The new Majasaya tenant, however, felt obliged to take the part of the Alasayas in the tink $u$, since they were the moiety who collected the tribute corresponding to his new land. Change of ayllu generally involves fighting for one's new group, and the new tenant aimed to change his loyalties and assume his new obligations to the Alasaya moiety in order to consolidate possession of his land. But the neighbouring Yuqhunas thereupon beat him up. The tenant then changed his tune, and claimed to be on the side of the Yuqhunas (Majasaya moiety), although the owner of the plot continued to pay tribute at the cabildo of the Kuymuris (Alasaya). The tenant began to fight on the side of the Majasayas, and even lectured the inhabitant of island 6 (a fervent AlaQuyana loyalist) on the need for local solidarity with the Majasayas. This new posture coincided, of course, with his own Majasaya origins; but it is significant that, during Corpus Christi in 1971, he still attended the feast of the AlaQuyana alferez (ritual sponsor from Alasaya) and thus received food and drink from the tribute-paying " owners » of the land. 
5. In the same way, the K'ultas of Llanquiri (island 1) fought on the side of the AlaQuyanas (Alasaya) who dominate the neighbourhood where their lands are situated. They could thereby maintain their vertical affiliations, although they were nervous of the surrounding Machas. Some were even beginning to «become Machas » by shifting their tribute-payments and obligations (such as postal services) from K'ulta to Macha. If carried through, this could have brought a change of ayllu, and the K'ultas would probably have joined the surrounding AlaQuyanas. Others, however, remained obstinate: they said their lands would continue K'ulta until the Macha returned a « quintal of gold » (quri kintal), allegedly lent them by passing K'ulta llama-herders to pay their tribute with ${ }^{31}$.

6. A particularly significant case concerns a couple from AlaQuyana (7) with one daughter and three sons who, lacking sufficient land in their cabildo of origin (puna identification Yuraqhari; valley locality Amutara), applied for permission to cultivate an unused piece of land in the territory of the Sullkhawis in nearby Ichurata (8). All were members of Alasaya moiety. Permission was granted provided that the children attended the local school in Ichurata (established by the Sullkhawis), that they helped maintain the paths in the area, and, as usual, that they would fight on the side of the Sullkhawis during tinkus and ch'ajwas.

This arrangement continued for two years, when both the woman's husband and their eldest son died. Unable to work the new plot alone, the widow and the remaining children then withdrew to AlaQuyana, where they lived on the lands that had belonged to the dead husband. This was permitted by the AlaQuyanas because there were still two sons to inherit their father's land: otherwise, the dead man's brothers would have had prior rights, and the widow would probably have returned to her parents and birth-kin. But soon after, the widow remarried with another AlaQuyana, this time from the puna, and then tried to return to the plot in Sullkhawi, since the new husband was unwilling to maintain his stepchildren on land from which he and his own children would be excluded.

Meanwhile the Sullkhawis, observing that the widow had abandoned the plot, had reallocated it to one of their own members who lacked land. They ceremonially dispossessed the widow: the ayllu held a " dry work-party " (ch'aki chuqhu; i.e. without chicha) during which each man, including the prospective possessor, ploughed and sowed a couple of furrows. The following year, the harvest was shared out between all the ayllu, and the repossessed plot was then handed over to its new occupier ${ }^{32}$.

Two points may be drawn from this example. First, the ceremonial dispossession shows both the reversionary right which the minor ayllu (and, beyond it, the moiety and maximal ayllu) can assert over land within its collective domain; and, simultaneously, the difficulty with which that right is reclaimed (since the plot had to be collectively ploughed, sowed, harvested and the produce distributed, before the ayllu could again dispose of the plot). Second, the entry of the AlaQuyana couple into the plot was regarded by their ayllu of origin as - potentially, at least - an increase of their own domain. This is shown by the fact that AlaQuyanas and Sullkhawis came to blows over the matter during the Corpus Christi fiesta for 1968.

Unfortunately, the key question concerning cabildo membership cannot be answered, for the AlaQuyanas were not paying tribute at this time due to the Second Agrarian Reform ${ }^{33}$. However, if the AlaQuyana couple had stayed in Sullkhawi, fulfilled their 
neighbourhood obligations as demanded by their « hosts », but continued paying their tribute with the rest of their own cabildo (Yuraqari), then all the conditions would have been fulfilled for the emergence of a new island. Equally, the case shows how circumstances could lead to the disappearance of an island with a shift in the social requirements of both parties.

Rather than expressing the unchanging situation of long-standing islands, then, some may also be seen as fluid expressions of a dynamic process: ephemeral « bubbles » that arise and burst, to use an alternative metaphor (Saignes 1978). We can infer that, even without a State apparatus disposed to guarantee security of tenure and access, circumstances could arise which would make small groups of distant colonists from the highlands, even single families, perfectly welcome in the heart of a different group already established in the lowlands, and perhaps themselves in need of allies to resist neighbouring pressures. New settlers might therefore be accepted at the price of their military support, but could find themselves expelled if their presence failed to suit their hosts - unless they could find effective backing from their own ayllu or other allies.

Our examples have clarified a fundamental point: the islands' survival is conditional on their willingness to fight on behalf of their surrounding " hosts ", even if this means fighting against their own moiety. During most of the year, they are submerged within a network of neighbourhood obligations which take precedence over other ties. It is as though there is agreement that these isolated « broken threads » must somehow be re-integrated into the homogeneous weave of local groups and territorialities, and a blind eye turned by their hosts to the few situations during the year where vertical affiliations re-emerge as paramount.

Even with these provisos, however, the situation of an island is often fraught: different characters respond to isolation in different ways. We have seen the case of the Alasaya man who, finding himself surrounded by Majasayas, felt driven to letting the land to another Majasaya; whereupon the tenant in turn found himself obliged to balance his solidarities between the locally dominant Majasayas and the Alasayas to whom his parcel still belonged. Again, the Majasaya island caught between a different ayllu of the same moiety and another group of Alasayas chose simply to alternate services and solidarities between Majasayas and Alasayas. On the other hand, a demand for land from within a host group may block the formation or persistence of an island, sometimes leading to cancellation and expulsion. This occurred with the widow from Alaquyana (Amutara) who, on remarrying, wanted to reoccupy her dead husband's parcel in Sullkhawi (Ichurata). She found herself formally dispossessed by her old hosts who preferred to give it to a landless ayllu comrade, a situation which provoked festive violence between these two Alasaya minor ayllus.

Evidently, island instabilities may provoke tensions between ayllus and moieties, and these can carry over into situations of ritual or formal violence (tinku). But there is one significant feature of neighbourhood alliances, which shows that, while moiety membership may be suspended in the interests of neighbourhood 
solidarity, there are limits placed on the scope of the violence that can be directed against one's own moiety. A Majasaya island warrior surrounded by Alasayas cannot hit just any Majasaya without exception; he might end up hitting his own kin and minor ayllu comrades. From people of both moieties I received testimonies affirming that no island should hit someone of the same minor; or churi ayllu, as himself. He can fight with his more distant moiety comrades, if compelled to do so by his engulfing neighbours; but not against those closest to him at the minor ayllu level.

This indicates how limits are placed on the socially desintegrative effects of an island's « forced betrayal » of its own moiety. The minor ayllu of vertical affiliation itself remains solidary and intact, while the other four ayllus of the same moiety become the enemies of an island obliged to fall into line with its neighbours of the opposing moiety. Who in this context are the island's greater enemies? Clearly, the four other ayllus of its own moiety; while its most powerful allies are its dominant neighbours of the opposing moiety. In this upsidedown scenario, the relations between the island and its own minor ayllu persist: they must not hit each other, although their unity is placed under strain by those " others » who provide the island with a local umbrella of protection.

\section{DISCUSSION}

Social difference among Northern Potosí endogamous cabildos, ayllus or moieties is often phrased in the literature in terms of structural alliance and opposition. In the last resort, who one fights defines who one may eat (or be eaten by); one shares food with one's friends and allies. This provides a fundamental criterion for social identification. But among valley « islands » the situation turns out to be more flexible, ranged along a continuum of successive gradations. Polar contrasts are redeployed between segmentary levels according to the tensions between distant tributary affiliations and those of neighbourhood ${ }^{34}$. Moiety alliances may be inverted in exchange for security of tenure in the interdigitated context of the valley " archipelago », sea of " bubbles », or - in more Andean terms - " weaving with broken threads ». The solubility of the moiety in the local context is thus counterweighed by the solidarity of the vertical minor ayllu.

At the same time, valley islands are forced to count on the protection of the other moiety that dominates their neighbourhood, while transforming into enmity their usual alliance with the four other ayllus that compose the rest of their own moiety. Evidently, then, the moiety opposition does not exert some overriding "structural imperative » over the formation of alliances. Rather, it can be fractured and re-deployed under local politico-economic and coercive pressures. In this context, only the vertical minor ayllu remains as the moral and solidary apex of vertical organization. 
I think we have here traces of a long-durational pattern of negotiations, echoing those entered into by the puna minor ayllus when they first began, in the Late Intermediate " period of warfare " (or perhaps long before), to descend from the high puna and intermingle with each other in the adjacent valleys, possibly establishing some islands that persist till now. Today's political accommodations seem to be inherent to the practice of vertical cultivation in the valleys by different groups of minor ayllus on the puna. The interdigitation of islands from different ethnic groups can be seen as a perfectly acceptable way of recruiting new members to help defend a weak neighbourhood. The modern situation may even reflect the process by which each moiety was originally formed on the puna from a flexible micro-federation of churi ayllus.

Each minor, or churi ayllu was in turn composed of what the Incas called « hundredths », or minimal ayllus, also with their ancestral mallki, sacred places of origin (huacas and paqarina), and vertical « runners ». Fixing the number of precisely five churi ayllus in each moiety may reflect Inca intervention; but the moieties themselves are almost certainly pre-Inca, in spite of their attribution today to the rising of the Inca-Christian Sun (Platt, Bouysse-Cassagne and Harris 2006; Platt 1996a). The data available suggest that today's minor and minimal ayllus on the puna, composed of several different intermarrying patrilineages each descended from an apical male or male-female couple (the « trunks » of " Houses », or troncos de casas, as they were called in 16th century Spanish, see Platt, Bouysse-Cassagne and Harris 2006), were probably the basic components from which Macha society was historically assembled ${ }^{35}$.

Accordingly, each minor and minimal ayllu would have been a tendentially endogamous group made up of smaller sets of intermarrying lineages, each stemming from their respective ancestral huacas on the puna (such as the chullpa mummies of senior House-founders, or remoter places of origin set in a sacralized landscape). Sets of intermarrying descent groups made up each of the " hundredths » (pachaqas) recognized by Inka Wayna Qhapaq, which were probably the ancestors of the colonial cabildos (another name for the minimal ayllus). Today, within each cabildo, groups of virilocal patrilines live surrounding their respective Calvary chapels (calvarios), where the local Cross (Tata Wilakrus, from vera cruz, Father True Cross) is kept: a phallic Cross, which, as we have seen, is a patron of warfare, sometimes painted with symbols of fertility, and often with a head of Christ in the middle ${ }^{36}$. It seems likely that the ancestral huaca of each group of patrilines within the Inca hundredth (pachaqa) has been replaced under the Spanish by a Calvary Cross. Remaining for most of the year in their little chapels, these crosses are taken out for May 3rd, the Festival of the True Cross, when, dressed in war-gear, they are carried by their congregations to the parish church in Macha. Within the church they hear Mass, focused on the Host of the Sun (Platt 1996), before coming out into the sunlight to give renewed courage (animu) and strength (kallpa) to their warrior-devotees' prowess in the tinku. 
We have seen that the valley « mixing » of ayllus at different segmentary levels juxtaposes households which on the puna belong to contrasted, spatially separated ayllus and cabildos. Hence pressure towards segmentary alliance can also come from the lowlands to the puna, rather than vice versa. For example, the maize harvest of San Marcos is a moment of maximal fusion for the whole Macha ayllu, expressed through the tinku in which, on each side, puna llameros participate in alliance with valley maize-farmers. We have seen that, in the valley town of Carasi, and at a higher level of segmentary alliance formation, Machas and Pocoatas unite to confront Laymis and Puracas (both part of the Laymi upper moiety of Chayanta, historically part of the Qaraqara federation and dependent on Macha). These higher-level alliances in the valleys can even propel similar alliances in the highlands, where allies may live much further away from each other and would otherwise have less incentive to enter into an alliance ${ }^{37}$.

I have suggested that these negotiations, reformulations and mutual concessions among ayllus yield traces of the political and religious negotiations by which they were historically constituted. Such negotiations may take place without an over-arching State able to impose on its tributaries an « umbrella » of peace, order and legitimacy ${ }^{38}$. At the same time, they take place within a warrior ethos, nurtured by collective competitions (tinkus) as well as by wilder confrontations (ch'ajwas), in which predatory aggression and defense, religious sacrifice and cannibalism, are situated at the constantly shifting frontiers of the political arena. Here, relatively ordered confrontation between rival bull-fighters dissolves into an unrestrained liberation of energies by each shapeshifting berserker warrior (ch'ajwa). Nevertheless, we have seen that there are also intermediary positions between the polar categories of ayllu-mate (expressed ideally by commensality) and enemy (or potential object of cannibalism).

These gradations are an essential part of the flexible political tapestry elaborated by the Aymara-speaking societies of the Altiplano, as later by the Incas: a veritable forest of runners, or suckers, reaching out from their distant parent mallki on the puna to mingle and root themselves in the warm lands, both as components of local settlements and as extensions of their respective groups. The ayllus probably constructed their segmentary system under the protection of the divinities of above (janajpacha) and those within the earth (ukhupacha), forces which dominated, sacralized and defined the contours of their social world. But this has not prevented people from constructing and shifting local loyalties and devotions, restructuring their federations, and moving their landlimits and even their cult centres, according to new demographic and political pressures. Social affiliations make people, but they are also constantly remade by them. Conflict and warfare are vehicles for this remaking.

We have seen that modern warfare invokes a situation akin to past-time, when confederational lords led armies of transforming warriors who preyed on their rivals while taking their heads as trophies for sacrificing to the ancestral spirits in 
the landscape ${ }^{39}$. The relation between shapeshifting, predatory warfare and shamanism among the people of mythic time is well-known in the modern Amazon; and our analysis has reminded us that similar themes have been played out at different times among Andean vertical societies. The transformation of shamans and warriors into wild beasts and back again is a deep-seated Andean theme, reiterated from the jaguar priests of Chavin (Burger 1996) to the military squadrons of Huari, each associated with a particular animal or bird transformation (Ochatoma Paravicino and Cabrera Romero 2001). It is picked up again for the aucaruma and Incas by Guaman Poma, who in the early 17th century illustrates the late 15th century transformation of Inka Otorongo («Inca Jaguar ») into the jaguar enemy of the lowlanders he was trying to conquer ${ }^{40}$. The presence of jaguar/human transformations among 17th century miners in Charcas has been further documented by Bouyssse-Cassagne (2004), and the theme of the transforming jaguar has continued in the use of jaguar skins during Altiplanic parades and dances during the Republican period (see for the 19th century Mercado 1991). The highland use of masks and skins may recall times when the upward geographical reach of the jaguar was higher then it is today ${ }^{41}$. Even now, chullpa lunar time irrupts into our own solar time whenever the sudden, uncanny appearance of an omen, in the form of an animal or bird, is interpreted as the persistent presence of the shapeshifting chullpas on the unstable edges of present time (Cereceda 1990). This other time, the time of the berserkers, also awaits us at the wild fringes of a social order constructed to tame those wild origins. Moreover, people regularly try to recover for society part of the creative energy of the unquiet dead through rituals, such as the tinku, or Carnival, necessary for good agropastural production (Harris 2000; Platt 1996a), or through their reincarnation as hungry devilish fœtuses which are later transformed into little Christian babies (Platt 2001).

The textile metaphor for Andean vertical control may be illuminated by modern weaving styles, such as the "mixed-up» or "confused " (chaxru) designs of the weavings of the Macha's neighbours: the Jallq'a of Murumuru (Ravelo) and Chuquisaca (Cereceda et al. 2001). Here, the fertile confusion of the Jallq'a inner world is expressed through a plethora of strange, heterogeneous mythological beasts (sometimes borrowed from modern advertising labels), which are contrasted with the ordered, luminous qualities of the nearby Tarabuco weavings. The dim, deceptive light of the Jallq'a inner world contrasts with the solar light of the Tarabucos, historically the Inca's settlers on the maizeproducing fringes of the Tawantinsuyu. In the Jallq'a valleys, we also find settlers from highland groups - Tinkipaya, even the altiplanic Killaka and Karanqa mixed with valley farmers from Caracara or Moromoro in a formation also called chaxru (Pacheco 1994; Mendoza and Patzi 1997; Platt, Bouysse-Cassagne and Harris 2006, pp. 265-272). Aesthetic confusion is in constant dialogue with sociological confusion. 
But the weaving parallel also brings us to the numerical underpinnings of Aymara social and political organization. In weavings, however « confused » the final appearance, there exists an underlying logic at the level of technique, issuing from the weaver's design objectives, her numerical warp and weft calculations, which are in the service of her aesthetic preferences. Can the same be said of social organization?

At the sociological level, Macha organization is achieved by means of the complex combination of a relatively small set of overlapping principles: the generative centre with radiating lines or, alternatively, « sandwich » relations along a complex frontier (chawpi); nested and overlapping divisions in two, three, four, five and seven, with their multiples, together constituting different levels of unity; the upper/lower, male/female or brother-in-law matrices and other ramifying and multivalent dualities; " reciprocity and redistribution », including the tributary relation, festive obligations and the lex talionis. For the tinku and the ch'ajwa are themselves based on a rhetoric of reciprocal exchange: ayni means « reciprocal labour relations » but also " vengeance »: " returning the ayni » (aynita kutichiy), equalizing a death with a death, is one of the aims of Macha warfare, as it was in the 16th century (Santo Tomás 1951 [1551]). Warfare again appears as part of the collective labour prestations, or « services in exchange for access to land ", of all ayllu members; and while it can have its festive and " playful » side (tinku), it may also become a source of pain and sorrow as well as triumph (ch'ajwa). Indeed, endocannibalism and exocannibalism become aspects of each other, since what is endo-warfare at a higher level of segmentation is exo-warfare at a lower. In combination, these principles configure or « frame » a lived experience that, for much of the time, flows flexibly through the « logic of forms » characteristic of Andean sociological and moral thinking (Platt 1978). But when the wild past of the ancient chullpas bursts through all restraining categories, and threatens to dissolve pre-existing ontological frontiers (as in the uncanniness of omens, in shamanism, or during ch'ajwas), this human and domesticated order is itself placed in doubt ${ }^{42}$.

The « island's point of view » challenges us, then, to unravel the specific forms of Andean social complexity, modular transformation and territorial reach. It epitomizes the ambiguities of life amidst valley "disorder », and the way vertical relations are reproduced and transformed through negotiated forms of violence and sociality. « Islands », like « broken threads », are occupied by people who must change the rules in order to stabilize their fragile existence as « loose ends ". They clutch at possible resolutions of their situation, such as those demanded of them by their hosts, but are still forced to live on the ambivalent margins between the moieties, which at the same time they subvert. Only the vertical minor ayllu, and its component cabildos, reaflirmed at each semestral tribute-paying ceremony, persists through time as a relatively unambiguous site of belonging and loyalty. 
To wind up the skein: our analysis has shown how Murra's « vertical archipelago » was indeed (as he foresaw) a tangle of competing loyalties, truces, alliances and enmities. We have seen how this situation was itself assimilated to the image of a weaving with broken threads, and how these threads had therefore to be reworked into line with the dominant power in each neighbourhood. The valleys are indeed " mixed-up ", at every level of social segmentation, but that does not mean that there is no way out of the apparent chaos. This " confused order » is expressed through a play of inversions and ambiguities that are valley transformations of the « dominant order » laid out on the puna. And this gives rise to a distinctive " island's point of view », situated at the internal fringes of Macha valley society, and mediating between the points of view of enemies and friends, as well as providing us with new ways of thinking about the political tensions and conflicts inherent to the island's position in different historical conjunctures.

The transformation of tinku into ch'ajwa spells a significant shift in the political and cosmological reach of Andean warfare, from transformation into domestic animals (bulls) to the shapeshifting of the berserker into a wild animal. While local authorities can try to control tinkus, encouraging individual warriors to confront other individuals, and doing their best to restrain the confrontation of allied ayllus with slings and stones, in ch'ajwas the idea of balance is itself at stake, and the aim is to move the fulcrum, conquering and destroying the opposing side, shifting the boundaries and their markers, or risking the same happening to ones' own side. Moreover, when peasant warrior alliances are turned, not against each other, but in open insurrection and rebellion against the State or its local representatives, ch'ajwa practices are turned towards local instances of the créole-dominated administration and government. One example of this can be documented in 1899 during the Bolivian Civil War, when the Indians of North Potosí came to grips with the Constitutionalist army of Severo Alonso in Tacarani: we read that « fragments of soldiers have been found, who were probably mutilated by the Indians in the heat of the battle... ", a clear reference to the predatory ch'ajwa practices of ayllu berserkers (cited in Platt 1987b, p. 316). This shift from domestic bulls to wild animals occurs as the " non-human » pole of transformation coincides with the shift from the ideal of equilibrium and balance between opposing sides (tinku) to the desire to kill, dismember and eat the organs of the prey (ch'ajwa). Such expansions in the scale of violence may constitute historical interventions which change the life of the wider society. They remind us that shifts from an emphasis on tinku to an emphasis on ch'ajwa, or vice versa, can be calibrated with a history of events, including periods of political tension and feud, and even insurrection, and hence with an absolute chronology, thereby indicating the possibility of relating shifts in the nature of human-animal transformations to their historical contexts, rather than seeing them simply as "essential» (if transformable) structures in 
a relativistic mythic and symbolic framework. The historical approach will surely be necessary also in the Amazon, and elsewhere ${ }^{43}$.

How, finally, are we to understand the dialectic between neighbourhood and verticality when the scale of each becomes enlarged? How do the practices of negotiated settlement, which we have uncovered on a relatively small scale through local fieldwork, respond to greater, more distant projections of highland vertical reach? Ethnohistorically, some of the answers have been found for the 16th century maize-producers of Tarabuco and Cochabamba: here distant settlers placed or confirmed by Inka Wayna Qhapaq were subsumed locally beneath the authority of the dominant regional lord, whether this be Aymuru, lord of the Yampara federation in Chuquisaca, or Kuysara, Mallku of the Charka federation in Cochabamba (Platt, Bouysse-Cassagne and Harris 2006). The segmentary scale of the islands and their alliances, which we have already seen growing as we descend the east-facing slopes of the Andes towards Mizque, here becomes truly colossal, since the units of alliance and opposition become the local representatives of whole federations and chiefdoms. In this case, Murra's emphasis on the transcendence by the Inca of the " purely ecological " motivation for vertical control should perhaps be qualified, since Inca strategy at the south-eastern frontier worked rather through an enlargement of the same principles of ever-extending vertical reach (Cochabamba maizefields, Chuquioma coca plantations, etc) in the interests of vastly amplified State agricultural projects which combined contingents of rotational workers from most of the Altiplano federations with silos, administrative centres and fortified military garrisons (Wachtel 1981; Platt, Bouysse-Cassagne and Harris 2006).

Further research will be needed to understand how vertical relationships are perceived from other ecological levels with other " points of view », such as from the chawpirana between the highlands and valleys of North Potosí; or how highland "order» was modified when projected, in the 15th and early 16th centuries, towards the coca-plantations in the semi-tropical yungas of Pocona, Tiraque and Chuquioma ${ }^{44}$; or, finally, by following the routes of highland invaders and settlers down to the pie-de-monte and lowlands, in order to direct these questions to groups in the forests and savannas, and down the headwaters of the Big and Little Pará... ${ }^{45}$. *

* Manuscrit reçu en janvier 2008, accepté pour publication en septembre 2008.

\section{NoTES}

1. Murra also asked whether coastal societies could have " islands " in the highlands (which has since been demonstrated, see Masuda, Shimada and Morris 1985); but he did not examine the possibility of eastern lowland chiefdoms having " islands " on the eastern slopes of the Andes. See Renard-Casewitz 2002, together with Daillant and Hirtzel (s. d.). 
2. In 1972, Murra's example of a « State island " was the coca-producers of the tropical valleys of Songo, below La Paz, who seem to have been a pie-de-monte, yunga-speaking group without lands in the highlands, although with some Aymara-speaking implants. They were probably incorporated into the Inca empire specifically to produce coca for the State. Different modes of incorporation of eastern tropical fringe groups into the Tawantinsuyu are reviewed in Saignes (1985, chap. I); see RenardCasewitz, Saignes and Taylor (1986); and Platt, Bouysse-Cassagne and Harris (2006).

3. Andean archaeologists distinguish - often with excessive linearity - between periods of State consolidation and expansion (Horizons) and the Intermediate or Formative periods, when regional polities prevail, each frequently at war with its neighbours (see Lorandi 1978). In fact, warfare may continue regionally at the margins of each State's effective reach, though there may be a tendency, as I have said, to transform it into a ritualized " game " or competition at moments of maximum State control (see Platt 1987a).

4. Early colonial documentation from 1579 and 1619 confirms that the Macha valley archipelago represents a case of long-durational stability, reaching back in some form to pre-Spanish, and probably pre-Inca, times. See Platt, Bouysse-Cassagne and Harris 2006 (part IV, documento 8, with its appendix); also the maps of Macha valley settlements (Platt 1996 and Figure 1).

5. As Franklin Pease (1985) realized, discontinuous territoriality and « verticality » can be found in many mountainous parts of the world, including Western Europe, in different social and historical periods. Less common, however, are those societies in which it constitutes such an integral and strategic dimension that it constrains the entire course of their social development, including the development of the State.

6. See Lakoff and Johnson 1980. For these authors, warfare is an example of a metaphor by which the modern West lives (as in " winning an argument » or in much market discourse), although warfare and violence are also powerful - as experience, as metaphors and in religious symbolism - in many other " warrior » societies, including the Macha.

7. An earlier draft of this article, given at a seminar on Murra's work at the London School of Economics in 1986, was entitled "Warfare and Alliance in an Andean Strawberry-Patch ».

8. "Wife-taking " affines " carry off " the bride in Macha just as the condor in a well-known tale carried off a girl to his rocky nest (Que. thapa; also a ritual name for a human house, or " home »). The condor-like role of brothers-in-law is made explicit during the marriage ceremony, and signifies a recognition of the wild substrate of human sexual affairs, parallel to that of the fighting-bull: attempts to harness these human-animal transformations and powerful energies lie behind the Indian marriage ceremony and establishment of a new household. For condors and bulls as expressions of Andean masculinity, see Harris (2000).

9. Guaman Poma (1980 [1613]) describes these transformations for the age of the aucaruma as follows: « they became great captains and valiant princes of pure courage they say that in the battle they turned themselves into lions [pumas] and tigers [jaguars] and foxes and vultures hawks and wild cats and so until today their descendants are named otorongo [jaguar] atoc [fox] condor anca [eagle] usco and wind acapana bird huayanay snake machacuay serpent amaro - and so their ancestral names and arms were called after other animals which their ancestors won in the battle they had... » cited in Platt 1987a. For shamanic transformations into condors in Macha today, see Platt 1997, Véricourt 2000; for the transformational experiences of present-day miners in Potosi, Absi 2003; see Bouysse-Cassagne (2004) for the transformations of miners into jaguars in the early colonial period, in the context of the wider prevalence of the shamanic jaguar cult in both highlands and lowlands. For the association of the mines with lightning and warfare, see Platt, Bouysse-Cassagne and Harris 2006 (part I).

10. Founded in the 1570 s by the inspectors (visitadores), priests and "reducers" (reducidores) charged with carrying out Viceroy Francisco de Toledo's resettlement programme, San Marcos replaced a pre-Hispanic settlement: Pichibisa. San Pedro de Macha was the «Indian town » for the bulk of the population on the puna (see Platt, Bouysse-Cassagne and Harris 2006, part IV). The Visita 
of San Marcos in 1619 shows much the same ayllu interdigitation and distribution as can be found today (see Platt 1996, map 1; Platt, Bouysse-Cassagne and Harris 2006, pp. 571-574).

11. The old kuraka of Macha Anansaya, don Agustin Carvajal (1977), told me in 1971 that he had had a dream that condors were circling above him, and was told by a yachaj (« knower », or shaman) that the dream meant he had not gone to make his sacrifices at Chiuquru Mountain, at the entrance to the valleys, and would fall ill and die if he didn't put this right. In a well-known Macha story, condors circling above a girl hiding in a q'ayru (shallow covered pit for storing potatoes) left her reduced to nothing but bones. The kuraka's dream was similarly interpreted as a threat of death by the condors, or mountain-spirits (jurq'us).

12. In the valleys of Provincia Charcas, this ambiguity was manipulated politically by peasant union leaders in the $1970 \mathrm{~s}$, who argued that valley farmers should separate from the puna and form part of the valley peasant unions, rather than retaining their links to traditional moiety and ayllu kingroups and authorities on the puna (see Platt 1982a).

13. This fiesta in San Marcos is described in Platt 1996. In 1971, the charango tuning known as walli mayu ("valley river») was the same as that used for the fiesta of the Cross on May 3rd (the charango is a little guitar with six double strings that traditionally uses an armadillo shell as a sounding-box). After the fiesta of the Holy Cross in San Pedro de Macha, the puna llama-herders begin their downward journey, strumming their charangos as they walk and accompanying their llamas as they follow along behind their lead-llama (delantero). For a full account of the seasonality of Macha music, with reference to the puna hamlet of Caanquira (cabildo Titiri, ayllu Taphunata, moiety Alasaya), see Stobart (2006).

14. Decimal organization in Macha is probably due to Inca influence. Documentary evidence suggests a close relation between Inka Wayna Qhapaq and the regional lords of Macha and Pocoata (see Platt, Bouysse-Cassagne and Harris 2006, document 16 and "Ensayo de interpretación »). The earliest explicit reference to cabildos as territorial groups comes from the Republican period.

15. In 1996, an attempt to map the physical distribution of these different groups was made using satellite equipment by Fernando Mendoza and Felix Patzi as part of a cartographic project funded by the European Community's " Programme of Peasant Self-Development » (PAC; see Mendoza and Patzi 1997, pp. 94, 116). I have collated information relating to San Marcos with data collected in 1970-1971 (Platt 1996, map 1): see in this article the Map and Appendix. Uncertainties remain, whose resolution will require Macha participation. It should also be remembered that satellite mapping totally ignores the traditional flexibility of ayllu land-limits in relation to local demographic variation (see Platt 1982b).

16. For the impact of the Law of Exvinculation (1874), and an analysis of the way in which the holdings of an originario may become progressively fragmented between other tribute categories, such as agregados and forasteros (or kantu rumas), see Platt 1982a, 1982b. See Harris 2000 for the Laymi, and Godoy 1990 for the Jukumani.

17. From the Aymara mantaña "enter ». Elsewhere, other terms emphasise different semantic features of these lands, such as the fact that they are a temporary grant from the community (mañay), or the rotative nature of their cultivation (muyuy). See Fonseca (1972), Harris (2000).

18. A strip of land flanked by two gullies, and stretching from high to low, is called a chhuru. Some families own an entire chhuru, containing a range of different microclimates; it may bear their surname: Choque chhuru, Mamani chhuru, etc.

19. See, for example, the letter from the kuraka of Alasaya to his counterpart of Majasaya, refusing help to the latter in a conflict with the neighbouring Pocoatas, published in Platt (1982a, chap. 5).

20. In the 16 th century these lands were cultivated by 10 minor ayllu mitayos (camayos), one for each ayllu, as collective minor ayllu plantations. The Carasi " common lands » were regarded as the richest lands in the whole of Macha. But after Toledo's Visita of 1573 (which confirmed Macha collective ownership) they were grabbed by Spaniards, and never given back in spite of repeated Macha protests to the Audiencia of Charcas (see Platt, Bouysse-Cassagne and Harris 2006, part IV). 
21. See Pacheco (1994). Also Platt, Bouysse-Cassagne and Harris (2006), where it is argued that the Laymi were part of the federation of Qaraqara in the 16th century, but were concentrated in the upper moiety of the Chayanta vertical strip, dependent on the dominant authorities in Macha and Pocoata. They may have been Qaraqara colonists, sent to share access to the tin and gold-mines of Llallagua and Amayapampa with the lower moiety of Chayanta, who were dependent on the capital of the Charka federation in Sacaca. The legend here recounted would then reflect a historical situation, when Laymis, Pocoatas and Machas all belonged to the same jurisdiction, based in Macha.

22. The insistence on the number twelve also coincides with the importance given to this number in ritual contexts, when libations are poured for Tata Chunkaiskayniyuj, "Father Twelve ». On the puna I was told that twelve was the ideal number of children in a family; that our fingers and toes should ideally consist each of two sets of six; that there were twelve mountains which surrounded each hamlet; that the ideal number of ayllus was twelve; that there were twelve miracles worshipped at twelve sanctuaries within and beyond the region of Northern Potosí. The importance of the number twelve may converge with the Christian tale of the Twelve Apostles, but it may also be an echo from a time prior to the Inca's imposition of decimal organization (Platt 1983, 2002; Platt, Bouysse-Cassagne and Harris 2006).

23. Other islands in Canton San Marcos, as well as many I collected in 1971, have since been mapped by Mendoza and Patzi (1997).

24. Subdivisions within cabildos are also found on the puna; see e.g. Stobart (2006, p. 140) for the divison of Caanquira estancia (cabildo Palquyu, minor ayllu Taphunata, moiety Alasaya) between « upper » and « lower » sections.

25. This contrast is also recognized by Enrique Mayer (2004). Unlike Saignes (1978, 1985), I do not find local solidarity and ayllu affiliation to be mutually exclusive, or inscribed within a unilineal temporal sequence, in spite of Bernabé Cobo's suggestion to this effect (Cobo 1964 [1660], book XI, cap. 23).

26. Compare the illuminating report by Governor Diez Canseco concerning tribute-payment practices in Chayanta Province during the early Republican period (cited in English translation in Platt 1984, pp. 10-12).

27. Before the abolition of the tambo in Macha during the 1970s, the system of turns had already been complicated by the creation of new Cantons: thus, the Majapichas and Alapichas had their own tambo apart in Qulqapujyu, near Chayrapata and Ocuri, and did not participate in the system of turns in Canton Macha. Similarly, the cabildos of Rosario (AlaQuyana) and Aullaqas (Waraqhata) belong to the Canton of Colquechaca, the capital of the modern Province of Chayanta. According to information given by the kuraka of Alasaya in 1971, the order within Canton Macha (Alasaya) was as follows: AlaQuyana ( 3 months), Taphunata and Waraqhata ( 3 months) and Sullkhawi ( 3 months). Six men were provided for each turn according to a further set of turns established at the level of the subsidiary cabildos. Thus, for example, the six men from AlaQuyana (excluding Rosario) were chosen as follows: Pichichhua (2), Yuraqari (2), Pumpuri and Chuqiqayara (1, alternating), and Kuimuri and Ayuma (1, alternating).

28. For the puna K'ultas, see Abercrombie 1998.

29. Vera, " true » in Spanish, but pronounced wila (meaning « blood ») in Aymara (see Platt 1996).

30. Cassandra Torrico has analyzed the Carnaval groups, and the forms of semaphore with flags developed by female dance-troop leaders for inter-moietal rivalry and communication (personal communication).

31. The antecedents of this conflict, as well as the contradictions which vertical aftiliations imply for the Republican system of administration, can be seen in a document of 1887 (Archivo Histórico de Potosí, Prefectura Departamental Expedientes 7475), where the Alasayas of Canton San Marcos can be found denouncing the K'ultas of " the Province of Paria, Department of Oruro » for " usurping » their lands under the pretext that « our ancient Governors would have given them the lands in pawn for the sum of 250 pesos ». The reference is clearly to the same event as the one I heard of in 1971. The origins of the K'ulta island are probably colonial. 
32. The widow appealed to the Secretary of Justice and Conflicts of the Federation of Peasant Unions in Banduriri (Charcas Province); but he upheld the position of the Sullkhawis saying that the widow should never have abandoned the plot if she hoped to have the Agrarian Reform on her side.

33. In the Macha valleys tribute-payments to the puna almost disappeared for a time, but were later revived as peasant defense of the traditional system grew. See Platt 1982a for the fluctuating levels of tribute collected between 1952 and 1980, and for the 1963 denunciation of President Paz Estenssoro, the local MNR leader Hugo Reinaga, and the 1953 Agrarian Reform. One friend said that the MNR revolution had in fact been a battle between the hacienda parti and the tasamanta parti, implying that the purpose of defeating the hacendados was so that their land could revert to the ayllu régime - an old revindication since the insurrections of the 18 th century and before, still strong today.

34. The number and complexity of these levels in pre-Hispanic and early colonial times was, of course, much greater, reaching out to the whole Province of Charcas, and even to the whole Qullasuyu south of Cusco. On this scale, the sociological calculus becomes correspondingly more elaborate (see Platt, Bouysse-Cassagne and Harris 2006, " Ensayo de interpretacion » and part V).

35. These apical Houses were also found at the level of ordinary tribute-payers, and during the early Republican period could still be re-founded on the occasion of each State inspection (visitas and revisitas) (Platt 1982a, 1982b).

36. The "diabolic » subtext of the symbolism of the crucified Christ was noticed in the early 17th century by the Archbishop of Charcas, Bernardino de Cárdenas, while extirpating idolatries among the miners of Potosi (see Bouysse-Cassagne 2004). This double reading of the crucified Christ can still be found today in the rural areas around Potosí (Platt 1996).

37. See, for example, the organization from the valleys of resistance to the implementation of the First Agrarian Reform Law of 1874 in North Potosí, analyzed in Platt 1987b.

38. It should be remembered that the Bolivian State in 1970-1971 had other things on its mind than to guarantee vertical links between puna and valleys, although the ayllus could invoke documentary support from the colonial and early Republican periods, which " fixed » the vertical distribution through successive documented rituals of confirmation (amojonamientos, revisitas, etc.).

39. Close to a " chullpa " settlement site in Macha I was shown a " chullpa cemetery ", made up of shallow pits marked by stones forming squares on the surface, beneath which a skull (presumably a trophy head) with no body was accompanied by ceramics and other offerings.

40. Inka Otorongo's transformation into a jaguar (otorongo) when battling with lowland groups was re-enacted by Titu Kusi Yupanki in 1561 in a threatening letter to the Corregidor of Cusco (Julien 2006).

41. According to 16th century testimonies, a jaguar is said to have killed an Inca's son as high up as the valleys of Sayapaya on the river Caine in Sacaca territory (Platt, Bouysse-Cassagne and Harris 2006 , p. 628). Jaguar presence in the highlands can also be detected symbolically in a riddle I collected on the Macha puna in 1971, which suggests an Andean interpretation of the Christian mass: tingri waqan, chaymanta kumtur tantakum, "the jaguar cries and then the condors gather together". The answer is the priest ringing the bells to call people to Mass, i.e. the condors gather to eat the remains of the jaguar's kill, just as the Indians go to church and follow the mestizo or white priest in consuming the body and blood of Christ.

42. For the "logic of forms », see Claude Lévi-Strauss (1966), Du Miel aux Cendres, cited in Platt 1978. It does not, however, exclude the simultaneous transformation of warriors into " animistic » expressions of "natural» forces, indicating a constant tension in the Andes between "other " perspectives and those of any formal logic.

43. In Mongolia, for example, it has been shown how the blurring of frontiers between the animal and the human is itself the recent result of the irruption of gold-mining, which has angered the spirits and led to the appearance of wolf-men, whereas before the categories of humans and animals were kept clearly distinct (High 2008).

44. For pre-Hispanic and early colonial settlement from different federations of the Collao and Charcas in the maize-producing Valley of Cochabamba and in the coca-growing yungas of Tiraque, as 
well as around the tin and silver-lead mining enclaves of Chayanta and Porco-Potosi on the puna, see Platt, Bouysse-Cassagne and Harris (2006). Here, too, distant affiliations were subsumed within local structures of authority.

45. The Amazon and the Paraná. For the existence of possible Charcas and Pakasa outliers in the eastern lowlands during the 16th century see e.g. the entrada of Francisco de Angulo to Chapare in 1588, published in part by Maurtua 1906 (vol. IX). The Pakasa are said to have been involved in battles with the Incas down there, as well as with their lowland neighbours, although the alliances in which they participated have not yet been clarified. For Inca presence in the eastern lowlands at Las Piedras, close to the meeting of the rivers Beni and Madre de Dios (near Riberalta), see Pärssinen and Korpisaari (2003). It has been suggested that the term " Carcaraes ", used in the Atlantic sources to refer to the "Caracaras " [Qaraqaras] of Macha and Chaquí, may also be present in the river name "Carcarañal ", indicating a distant "island " of these same people at the junction of the rivers Carcarañal and Paraná near Cabot's fort of Espiritu Santo. See, for example, the letter by Luis Ramírez (1528), published in José Torre Revello (1941, vol. I, p. 91, document 16). I thank Isabelle Combès for a copy of this text.

\section{REFERENCES CITED}

\section{ABERCROMBIE Thomas}

1998 Pathways of memory and power. Ethnography and history among an Andean people, Wisconsin University Press, Madison.

Absi Pascale

2003 Los ministros del diablo, PIEB (Programa de Investigación Estratégica en Bolivia), La Paz.

\section{BOUYSSE-CASSAGNE Thérèse}

2004 "El Sol de adentro: wakas y santos en las minas de Charcas y en el lago Titicaca (siglos XV-XVII) ", Boletín de Arqueología, 8, pp. 59-97.

BURGER Richard

1996 Chavin and the origins of Andean civilization, Thames and Hudson, London.

Cereceda Verónica

1978 "Sémiologie des tissus andins », Annales ESC, 5-6, pp. 1017-1035.

1990 "A partir de los colores de un pájaro », Boletín del Museo Chileno de Arte Pre-Colombino, 4, Santiago de Chile.

Cereceda Verónica, Jhonny DÁvalos and Jaime Mejía

2001 A difference and a meaning: the textile designs of Tarabuco and Jalq'a, ASUR (Antropólogos del Sur Andino), Sucre.

Coвo Bernabé

1964 Historia del Nuevo Mundo, [s. n.] coll. « Biblioteca de Autores Españoles » XCII, Madrid [1660].

Daillant Isabelle and Vincent HiRTzel

s. d. "La migración de un nombre: raices de un equívoco etnológico ("Moxos", siglos XVI-XVII) » [oral communication]. 
Dransart Penny

2002 Earth, water, fleece and fabric: an ethnography and archaeology of Andean camelid herding, London, Routledge, London.

\section{FLORES OCHOA Jorge}

1979 Pastoralists of the Andes: the alpaca herders of Paratia, Institute for the Study of Human Issues, Philadelphia [1977].

\section{Fonseca Martell César}

1972 Sistemas Económicos Andinos, Universidad Mayor de San Marcos, Lima.

\section{GoDoy Ricardo}

1990 Mining and agriculture in highland Bolivia: ecology, history and commerce among the Jukumanis, University of Arizona Press, Tucson.

\section{Guaman Poma de Ayala Felipe}

1980 Nueva Corónica y Buen Gobierno [1613], transcript. and ed. John V. Murra, Rolena Adorno and George Urioste, Siglo XxI, Mexico.

Harris Olivia

2000 To make the earth bear fruit, Institute of Latin American Studies, London.

High Mette

2008 "Wolves, spirits and humans in the Mongolian goldmines », paper delivered at the colloquium Humains, animaux, plantes et choses: la notion de personne en Amazonie et Sibérie contemporaines, Juin 2008, Musée du Quai Branly, Paris.

JuLIEN Catherine

2006 "Titu Cusi amenaza la guerra », in Ulises Juan Zevallos Aguilar, Takahiro Kato and Luis Millones (eds), Ensayos de cultura virreinal latinoamericana, Fondo Editorial de la Facultad de Ciencias Sociales de la Universidad Nacional Mayor de San Marcos, Lima, pp. 79-98.

LAKOFF George and Mark JoHNSON

1980 Metaphors we live by, University of Chicago Press, Chicago.

Lévi-STrauss Claude

1966 Du Miel aux Cendres, Plon, Paris.

LORANDi Ana María

1978 "Les "horizons" andins: critique d'un modèle ", Annales ESC, 5-6, pp. 921935 .

Masuda Shozo, Izumi Shimada and Craig Morris

1985 Andean ecology and civilization. An inter-disciplinary perspective on Andean ecological complementarity, University of Tokyo Press, Tokyo.

Maurtua Victor M.

1906 Juicio de límites entre Perú y Bolivia, VIII, Imprenta de los Hijos de M. G. Hernández, Madrid. 
MAYER Enrique

2004 The articulated peasant. Household economies in the Andes, Westview, Boulder [1985].

Mercado Melchor María

1991 Album de paisajes, tipos humanos y costumbres de Bolivia (1841-1869), Banco Central de Bolivia/Archivo y Biblioteca Nacionales de Bolivia, Sucre.

Mendoza Fernando and Félix Patzi

1997 Atlas de los Ayllus del Norte de Potosí. Territorio de los antiguos Charka, Comisión Europea, Programa de Autodesarrollo Campesino, Potosí.

MurRa John V.

1975 Formaciones políticas y económicas del mundo andino, Instituto de Estudios Peruanos, Lima [1972].

2003 El mundo andino. Población, medio ambiente y economía, Instituto de Estudios Peruanos, Lima [1973].

Ochatoma Paravicino José and Martha Cabrera Romero

2001 "Ideología religiosa y organización militar en la iconografía del area ceremonial de Conchopata », in Wari. Arte Precolombino peruano, Centro Cultural del Monte, Sevilla, pp. 173-211.

Pachacuti Yamqui Salcamaygua Joan de Santacruz

1993 Relación de Antiguedades deste Reyno del Piru, edited by Pierre Duviols and César Itier, Institut Français d'Études Andines, Lima/Centro de Estudios regionales Andinos « Bartolomé de las Casas », Cusco [1613].

PACHECo Diego

1994 Machas, Tinkipayas y Yamparas, CIPRES (Centro de Ingeniería en Proyectos Regionales Económicos y Sociales), Sucre.

PÄrSSINEN Martti and Antti KorPISAARI (eds)

2003 Western Amazonia-Amazônia ocidental. Multidisciplinary studies on ancient expansionistic movements, fortifications and sedentary life, Renvall Institute, Publications 14, Helsinki.

PeAse Franklin

1985 "Cases and variations of verticality in the Southern Andes ", in Shozo Masuda, Izumi Shimada and Craig Morris (eds), Andean ecology and civilization. An inter-disciplinary perspective on Andean ecological complementarity, University of Tokyo Press, Tokyo, pp. 141-160.

\section{Platt Tristan}

1978 "Symétries en miroir. Le concept de yanantin chez les Macha de Bolivie », Annales ESC, 5-6, pp. 1081-1107.

1982a Estado boliviano y ayllu andino: tierra y tributo en el Norte de Potosí, Instituto de Estudios Peruanos, Lima.

1982b " The role of the Andean ayllu in the reproduction of the petty commodity regime ", in David Lehman (ed.), Ecology and exchange in the Andes, Cambridge University Press, Cambridge, pp. 27-69. 
1983 "Conciencia proletaria y conciencia andina: qhuya runa y ayllu en el Norte de Potosí », HISLA (Historia de Estudios Latino-Americanos), 2, pp. 47-73.

1984 "Liberalism and ethnocide in the Bolivian Andes", History Workshop Journal, 17, pp. 3-18, Oxford.

1987a «Entre ch'axwa y muxsa: para una historia del pensamiento político andino ", in Thérèse Bouysse-Cassagne, Olivia Harris, Tristan Platt and Veronica Cereceda (eds), Tres reflexiones sobre el pensamiento andino, HISBOL, La Paz, pp. 61-132.

1987b "The Andean experience of Bolivian liberalism. Roots of rebellion in Chayanta », in Steve Stern (ed.), Resistance, rebellion and consciousness in the Andean peasant world (18th-20th centuries), Wisconsin University Press, Madison, pp. 280-323.

1996 Los guerreros de Cristo: cofradías, misa solar y guerra regenerativa en una doctrina surandina (siglos $x v i l 1-x x$ ), Ediciones Plural, Asur $n^{\circ} 5$, Sucre/La Paz.

1997 "The sound of light: emergent communication through Quechua shamanic dialogue ", in Rosaleen Howard-Malverde (ed.), Creating context in Andean cultures, Oxford University Press, Oxford, pp. 196-226.

2001 «El feto agresivo: parto, formación de la persona y mitohistoria en los Andes ", Amuario de Estudios Americanos, LVIII (2), pp. 633-678.

2002 "Without deceit or lies": variable chinu readings during a Sixteenth century tribute-restitution trial ", in Jeffrey Quilter and Gary Urton (eds), Narrative threads: accounting and recounting in Andean khipu, Texas University Press, Austin, pp. 225-265.

Platt Tristan, Thérèse Bouysse-Cassagne and Olivia Harris

2006 Qaraqara-Charka. Mallku, Inka y Rey en la provincia de Charcas. Historia antropológica de una confederación aymara, Institut Français d’Études Andines, Fundación Cultural del Banco Central de Bolivia, Plural Editores, La Paz/University of St Andrews, St Andrew/University of London, London.

Platt Tristan and Pablo Quisbert

2007 «Knowing silence and merging horizons: the case of the great Potosi cover-up ", in Mark Harris (ed.), Ways of knowing. New approaches in the anthropology of knowledge and learning, Berghahn, Oxford.

Presta Ana-María (ed.)

1995 Espacios, fronteras, etnias, ASUR, Sucre.

RENARD-CASEIVITZ France-Marie

2002 «Social forms and regressive history: from the Campa cluster to the Mojos and from the Mojos to the Landscaping terrace-builders of the Bolivian savanna », in Jonathan Hill and Fernando Santos Granero (eds), Comparative Arawakan Histories. Rethinking Language Family and Culture Area in Amazonia, University of Illinois Press, Urbana/Chicago, pp. 123-146. 
Renard-Casewitz France-Marie, Thierry Saignes and Anne Christine Taylor

1986 L'Inca, L'Espagnol et les sauvages, Éditions Recherche sur les Civilisations, Paris.

SAIGNES Thierry

1978 "De la filiation à la résidence: les ethnies dans les vallées de Larecaja », Annales ESC, 5-6, pp. 1160-1181.

1985 Los Andes orientales: historia de un olvido, IFEA, Lima/CERES (Centro de estudios de la realidad social), Cochabamba.

SANTo Tomás Domingo

1951 Lexicon, o vocabulario de la lengua general del Perú, Universidad Mayor de San Marcos, Lima [1551].

SERULNIKOV Sergio

2006 Conflictos sociales e insurrección en el mundo colonial andino. El norte de Potosí en el siglo xvil, Fondo de Cultura Económica, Buenos Aires.

STOBART Henry

2006 Music and the poetics of production in the Bolivian Andes, Ashgate Publishing Limited UK, coll. « SOAS Musicology Series », Aldershott.

TANDETER Enrique

1992 Coacción y mercado: la minería de la plata en el Potosí colonial, 1692-1826, Centro de Estudios Regionales Andinos Bartolomé de Las Casas, Cusco.

Torre Revello José (ed.)

1941 Documentos históricos y geográficos relativos a la colonización rioplatense, vol. 1, Talleres S. A. Casa Jacobo Peuser Ltda, Buenos Aires.

Troll Carl

1968 Geo-ecology of the mountainous regions of the tropical Americas, Dümmler, Colloquium Geographicum 9, Bonn.

Uzendoski Michael A.

2004 "The horizontal archipelago. The Quijos/Upper Napo regional system ", Ethnohistory, 51 (2), pp. 317-357.

VÉRICOURT Virginie de

2000 Rituels et croyances chamaniques dans les Andes boliviennes. Les semences de la foudre, L'Harmattan, Paris.

Viveiros de CASTro Eduardo

1998 "Cosmological deixis and Amerindian perspectivism ", Journal of the Royal Anthropological Institute, n. s. 4 (3), pp. 469-488.

WACHTEL Nathan

1981 «Los mitimas del valle de Cochabamba: la política de colonización de Wayna Capac », Historia Boliviana, 1 (1), pp. 21-57. 


\title{
APPENDIX: SEGMENTARY ORGANIZATION OF MACHA (KEY TO MAP « DISTRIBUTION OF MACHA LANDS IN SAN MARCOS DE MIRAFLORES $»)$
}

\author{
by maximal ayllu, moiety, churi ayllu and (where possible) cabildo
}

\begin{abstract}
Note: Cabildo names were first collected on the puna in 1971, and have now been collated with the lists in Mendoza and Patzi 1997. Both sources are combined in the map. The numbers refer to the numbered areas on the map. The extent of each area is not precise, many cabildos have remained unidentified. Errors will no doubt be found. The only way of doing the map $100 \%$ accurately is with the direct participation of re-empowered moiety authorities backed with further archival research. Macha lands in the Department of Chuquisaca (Provincia of Yamparaes) have been omitted; also those in Carasi. These still await investigation and detailed mapping. [TP = Platt 1996; MP = Mendoza y Patzi 1997.]
\end{abstract}

\section{K'Ulta. Moiety Alasaya}

\section{Ayllu Kullana. 1. Llanquiri}

The K'ulta Kullanas have an annex chapel of their own in the parish of San Marcos de Miraflores: San Pedro de Llanquiri, close by the chapel of the local Macha AlaQuyanas, Santa Ana de Lluchhu (see Platt 1996a). Though in 1971 some Llanquiris protested strongly that the tributes and services for their lands in Llanquiri were still owed to Santa Barbara de K'ulta, situated on the Oruro frontiers with Macha's high puna lands (see Abercrombie 1998), others felt that they should switch to paying services and tributes to Macha, merge with the AlaQuyanas of Lluchhu and "become Machas ». In 1997 MP imply that this process was complete by the time of their Atlas, as they represent the K'ultas of Llanquiri as « ayllu AlaQuyana » of Macha. Further research is needed on this point.

\section{Macha. Moiety Alasaya}

\section{Ayllu AlaQuyana}

Cabildo Ayuma, in Lluchu and Chayta 2, 3

Cabildo Chuquiqayara, $\mathrm{n} / \mathrm{d}$

Cabildo Kuymuri, of Kuymuri 5, 6

Cabildo Phichichhua, in Lluchu and Chayta 2, 3

Cabildo Pumpuri, in Lluchu and Chayta 2, 3

Cabildo Rosario, $\mathrm{n} / \mathrm{d}$

Cabildo Yuraqari, in Amutara, 7

In Lluchhu and Chayta those from cabildos Ayuma, Pichhichua and Pumpuri are all interdigitated (chajrusqa). Chuqui churu (40) is unassigned. 
Ayllu Sullkhavi

Cabildo Challwiri

Cabildo Salinas

Cabildo Qharipurqu

Cabildo Kiuja

Cabildo Tanki

No data for distinction by cabildo in the valleys, only by toponyms between the Jatun Sullkhawis ("Greater Sullkhawis ») of Ichurata (8) and the Juchuy Sullkhawis (" Lesser Sullkhawis ») of Chharichhari (9), cabildos unknown.

\section{Ayllu Waraqhata}

Cabildo Awllakas

Cabildo Kantakanta

Cabildo Kañuquta

Cabildo Usquria

Cabildo Waylloma

No data for distinction by cabildo in the valleys, only by toponyms between the Waraqhatas of Payluta (10), Pariya (11), Samuma (12), Sayaqa (13), Lupi (41), Niqiri (42), cabildos unknown.

\section{Ayllu Taphunata}

Cabildo Titiri

Cabildo Palquyu

Cabildo P'uqira

No data for distinction by cabildos in the valleys, only by toponyms between the Taphunatas of Chawarani (14 MP Chawarani; TP Qolqapampa) and Qarpani (15), cabildos unknown.

\section{Ayllu Alapicha}

Cabildo Tuqhuqari

Cabildo Ch'iaraqi

Cabildo Lurukachi

Cabildo Turku

Cabildo Qullpa

[Cabildo Jamach'iri: MP]

No data for distinction by cabildos in the valleys, only by toponyms between Alapichas of Urqhapampa (16), Altu Luma (17), K'aspikancha (18), Janq'uma (19), Umupampa (43). At present, only Janq'uma can be assigned to cabildo Tuqhuqari.

\section{MOIETY MaJASAYA}

Ayllu MajaQuyana

\section{Cabildo Kutañisu}

Cabildo Waykuta 
Cabildo Chajrani

Cabildo Jiruq'uma [not in MP]

Cabildo Umajila (or Jatun Qullana)

Cabildo Yuqhuna [MP assigns it to Sullkhata]

Cabildo Phurki [MP assigns it to Majapicha]

Few data for distinction by cabildos in the valleys, easier by toponyms between MajaQuyanas of Qayanqa (20), Yuqhuna (cabildo and toponym; 21), Triguira (22), Mathariri (23), Chuqipampa (24), Lluchu (cabildo Waykhuta; 25).

\section{Ayllu Sullkhata}

Cabildo Juluch' $i$

[Cabildo Yuqhuna: MP. TP assigns it to MajaQuyana]

Few data for cabildos in valleys, distinctions by toponyms, as Sullkhatas of Ch'alloma (26), Waramaya (27), uncertain (28), Lawa Apachita (29).

\section{Ayllu Kunthawata}

Cabildo Llust'aqi

[Cabildo Q'illuq'asa: MP]

Only one cabildo identified in the valleys, the rest by toponyms: Kunthawatas o Kuñurani (30), Durasnillo (31), Llust'aqi (32), Kunthawata (33), Wankarani (34), Chuñu Jarana (44).

\section{Ayllu Wakhuata}

Cabildo Milluri

Cabildo Pumpuri

Cabildo Llust'aqi

No data for distinction by cabildos in the valleys, only by toponyms: Wilakota ( 35 ; jatun wakhuata, " great Wakhuata »), Ilili (36; churi wakhuata, " child Wakhuata »), Sikuta (37; churi wakhuata).

\section{Ayllu Majapicha}

Cabildo Tumaykuri

Cabildo Rukuruku

Cabildo Pichikachi

Cabildo Lluchhu

Cabildo Milluni

[Cabildo Tarwaki: MP]

[Cabildo Pastupampa: MP]

[Cabildo Phurki: MP]

[Cabildo Chayrapata: MP]

[Cabildo Jut' $i$ : MP]

No data for distinction by cabildos in the valleys, only toponyms: e.g. Waranqa (38), Qatachilla (39). 